\title{
Interdisciplinary Research into the Legacy of the Medieval Metropolis of Soba in a Modern Khartoum Suburb
}

\author{
Mariusz Drzewiecki (D) Maciej Kurcz (D) Joanna Ciesielska (D) \\ Tomasz Michalik (D) Ewa Czyżewska-Zalewska (1) \\ Krzysztof Kiersnowski (D) Robert Ryndziewicz
}

Accepted: 11 August 2021 / Published online: 14 September 2021

(C) The Author(s) 2021

\begin{abstract}
Recent research at Soba focuses on the tangible and intangible heritage of the medieval capital of Alwa kingdom, whose remains cover approximately 275 ha. About 222 ha of this area has been built up or transformed into agricultural land in the past 30 years. An ethnographic survey was also carried out in the built-up area to understand how the residents engage with the archaeological heritage and material remains. The undeveloped area of the capital (53 ha) was the focus of interdisciplinary archaeological fieldwork conducted in 2019 and 2020. A large-scale geophysical survey, using a fluxgate gradiometer and ground-penetrating radar, was initiated in the undeveloped area, and excavation trenches were opened to verify distinctive magnetic anomalies. Along with the ethnographic and geophysical data,
\end{abstract}

M. Drzewiecki $(\bowtie) \cdot J$. Ciesielska $\cdot$ T. Michalik ·

E. Czyżewska-Zalewska

Polish Centre of Mediterranean Archaeology, University

of Warsaw, Prosta 69, 00-838 Warsaw, Poland

e-mail: m.drzewiecki2@uw.edu.pl

M. Kurcz

Institute of Culture Studies, University of Silesia,

Katowice, Poland

K. Kiersnowski

Norwegian University of Science and Technology,

Trondheim, Norway

R. Ryndziewicz

Institute of Archaeology and Ethnology, Polish Academy

of Sciences, Warsaw, Poland the study of the pottery, burials, and stratigraphic sequence (supplemented with radiocarbon dates) provides new insights into the spatial organization of the medieval capital.

Résumé Les recherches récentes à Soba examinent le patrimoine matériel et immatériel de la capitale médiévale du royaume d'Alwa, dont les vestiges couvrent environ 275 ha. Environ 222 ha de cette superficie ont été aménagés ou transformés en terres agricoles au cours des 30 dernières années. Une enquête ethnographique a également été menée dans la zone bâtie pour comprendre comment les habitants interagissent avec le patrimoine archéologique et les vestiges matériels. La zone non aménagée de la capitale (53 ha) ont fait l'objet de travaux de terrain archéologiques interdisciplinaires menés en 2019 et 2020 . Une prospection géophysique à grande échelle, à l'aide d'un gradiomètre Fluxgate et un radar à pénétration de sol, a été lance dans la zone non aménagée, et des tranchées d'excavation ont été ouvertes pour vérifier les anomalies magnétiques distinctives. Avec les données ethnographiques et géophysiques, l'étude des poteries, des inhumations et de la séquence stratigraphique (complétée de datations au radiocarbone) permet de mieux comprendre l'organisation spatiale de la capitale médiévale.

Keywords Soba $\cdot$ Alwa kingdom $\cdot$ Medieval Sudan · Ethnographic research · Geophysical survey 


\section{Introduction}

Between the sixth and early sixteenth centuries, the confluence of the White Nile and the Blue Nile was the heartland of the kingdom of Alwa, traditionally known as a Christian realm. Its capital thrived for almost a millennium at Soba on the right bank of the Blue Nile. According to the tenth-century traveler and emissary, Ibn Selim al-Aswani, the city had fine houses and large monasteries, churches with rich furnishing, a district inhabited by Muslims, and beautiful gardens (Vantini, 1975, p. 613). The remains of Soba span approximately $2.75 \mathrm{~km}^{2}$, making it one of the largest archaeological sites in Sudan.

The account of Ibn Selim al-Aswani was partly confirmed by archaeological work conducted in the twentieth century (Somers Clarke, 1912, p. 34-38; also see Abdel Rahman, 2000; Budge, 1907; Shinnie, 1955; Welsby, 1998; Welsby \& Daniels, 1991). By the end of the twentieth century, only around $1 \%$ of the site had been investigated in detail (Welsby, 1998, p. 21). Research continued at the site in recent years, but only brief rescue excavations were conducted, and the results have not yet been published. The previous excavations revealed the remains of monumental architecture and building complexes of various sizes, as well as many imports from the Mediterranean and the Far East and locally-made luxury goods.

Soba is covered with numerous mounds, but no architectural remains are visible except for four stone columns. There are also a few heavily deteriorated mud-brick walls in the old archaeological trenches.
Thus, the spatial organization of the medieval city is still largely unknown. We also know very little about the different districts of Soba, industrial areas, public places, larger cemeteries, and the street plan. With only a few short descriptions in written sources and a lack of sketches from the early travelers, Soba is one of Sudan's least-known urban archaeological sites.

In the last 50 years, the landscape of Soba has witnessed transformation from a rural, sparsely inhabited area a few kilometers from Khartoum to being a suburb of the modern capital. The archaeological site was slowly built up or leveled for agricultural or domestic purposes, especially in the last 20-30 years when an increasing number of settlers arrived in the region. In 2018, of the 275 ha archaeological site, only 53 ha was left relatively untouched. The development trajectories of modern Soba can be followed using historical satellite imagery (Fig. 1). The stories of these later settlement processes, including details of medieval remains discovered during the construction of modern houses, may still exist among the communities of Soba today. Thus, there may still be an archaeological potential in the built-up areas of the site. To access these stories, an ethnographer interviewed people living in Soba in November and December 2019. The data was collected in SobaGen`ab-a community at the southern and southeastern part of the archaeological site. The general effort was to obtain a broad perspective of social life in the study area through everyday observations and semistructured interviews. The approach was qualitative because of the initial character of the fieldwork. Data
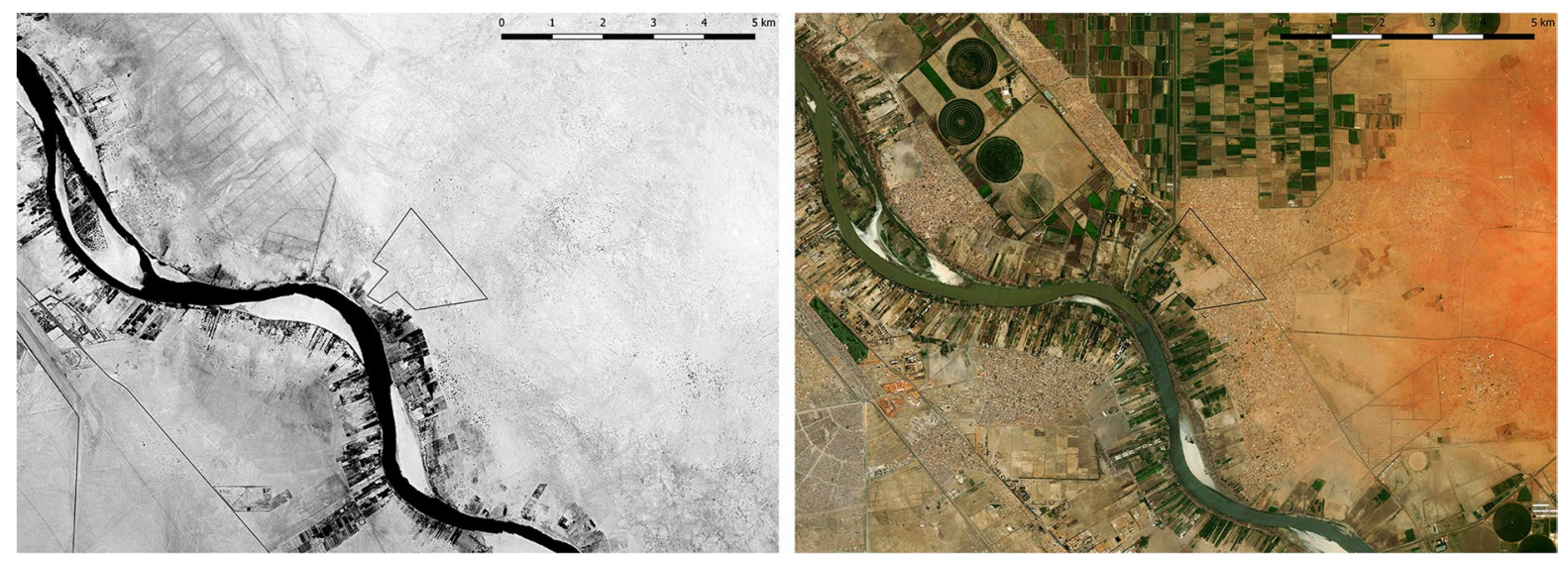

Fig. 1 Soba in 1970 (left - Corona image) and 2014 (right - Bing satellite), the archaeological site is marked by a polygon (prepared by Mariusz Drzewiecki) 
collected was anonymous and cannot be traced back to the interviewee since residents often show or talk with the researchers about archaeological objects they have come across in their homes or fields. ${ }^{1}$

Altogether 21 individuals were interviewed, and numerous people were spoken to briefly during casual meetings in the market, on the street, and at shops and restaurants. During initial talks, the key respondents, 18 men and three women, expressed a sound knowledge of local oral histories related to the archaeological site. The gender imbalance is noted and should be counterbalanced in future fieldwork seasons. The interviews are aimed at acquiring insights into how the respondents understand the remains of the past. Hence, the respondents were asked about stories and legends connected to the remains and accounts of accidental discoveries. There were also questions about whether the residents kept any of the artifacts from medieval Soba in their houses and why. Another objective was to understand modern attitudes toward the archaeological site, identify various interest groups within the local community, and understand the local perception of archaeological heritage. The study is a first step in developing long-term strategies to protect Soba's archaeological heritage and present it to the public in collaboration with representatives of various local groups.

The surviving 53-ha site offers excellent research potential. The medieval architectural remains are directly under the surface. The postmedieval occupation in Soba was, according to previous research, scattered and not intensive. Some small postmedieval artifacts have been recorded, but no postmedieval architectural remains have so far been noted. This is a unique situation since the other Nubian capitals were inhabited long after the Medieval period (Edwards, 2004, p. 274-275). Dongola, the central city of

\footnotetext{
1 The ethical base for ethnographic research in Soba is the "Guidelines of the Association of Social Anthropologists" (https://www.theasa.org/downloads/ASA\%20ethics\%20gui delines\%202011.pdf, accessed on 26.07.2021). Moreover, the project was evaluated in Poland by the Arts, Humanities and Social Sciences panel of the National Science Centre (Poland) based on the "Code of the National Science Centre on Research Integrity and Applying for Research Funding" (https://www.ncn.gov.pl/sites/default/files/pliki/Code-of-theNational-Science-Centre-on-Research-Integrity.pdf accessed on 26.07.2021). In Sudan, it was approved by the National Corporation for Antiquities and Museums of Sudan (NCAM).
}

Makuria, for example, was constantly occupied until the 1960s, while at Faras (the metropolis of Nobadia, flooded in the twentieth century during the filling of the reservoir lake for the Aswan High Dam), a large postmedieval fort was built over the central part of the medieval town. The easy access to older layers makes Soba an excellent and rare place to study medieval urbanization.

The architectural remains directly under the sand can be used to test various remote sensing methods. We initiated a search for the most suitable techniques to identify buried archaeological features and a method that could be successfully applied in the other parts of the site, including the built-up area and fields. In 2019 and 2020, a large-scale geophysical survey was conducted at Soba, using fluxgate gradiometer (20.5 ha) and ground-penetrating radar-GPR (4 ha). The prospection was supplemented with test trenches, aiming to identify features associated with the various magnetic anomalies. The geophysical prospection covered the parts of the city which were not investigated in the past. It provided a large amount of data on the location of various archaeological and natural features.

On the other hand, excavation gave insight into the complexity of selected areas, identifying successive occupation phases and yielding massive amounts of small finds (pottery, glass, metal, and stone) and organic samples (especially charcoal samples for radiocarbon dating). This article presents the results of the research, discussing challenges, limitations, and opportunities for future studies at the site in the context of a densely populated area. This interdisciplinary ethnological, geophysical, and archaeological study (including chronometrically dated stratigraphy and pottery and burial analysis) gives a multifaceted image of what was once a vibrant city. The study reveals new insights into the spatial organization of Soba and the changes that the city went through in its long existence.

\section{"Modern Soba" and "Past Soba" Intertwined: Cultural Anthropology in Action}

For the Sudanese, the term Soba has essentially two meanings today. First, it means the former capital of the kingdom of Alwa ("Past Soba"). Second, it is 
the suburban zone of the Khartoum agglomeration ("Modern Soba"). "Past Soba" and "Modern Soba" (henceforth, without quotation marks) are intertwined in time and space and their relationships have recently become antagonistic due to accelerating urbanization processes. The ethnographic study carried out in 2019 was the first of its kind in Soba. Ethnographic research with local communities in various regions of riverine Sudan was conducted throughout the twentieth century by anthropologists, language specialists, and colonial administration officials. These studies provide insights into oral traditions and local understanding of archaeological heritage (e.g., Jackson, 1926; Kurcz, 2007; Osman, 1992). In recent years, ethnographic studies have been developed and used in projects aiming to engage local communities in archaeological research and heritage management. For such undertakings to work, a two-way knowledge transfer is needed through public meetings, ethnographic interviews, and sociological methods (such as questionnaire survey). Many community engagement actions have focused on rural settlements in the Middle Nile valley where most people have a lasting attachment to land developed at least for two or three generations, sometimes longer, and newcomers constitute a minor part of the population (e.g., Bradshaw, 2017; Fushiya \& Radziwiłko, 2019; Tully, 2014, 2015). On the other hand, Soba is a suburban region where rapid population increase is a relatively new and ongoing process (for the last 30 years). The majority of people in Soba are recent settlers who are currently establishing their connections with their surroundings in a densely populated region.

In this aspect, the ethnological research in Soba is opening a new research field in Sudan, but the result should be treated as a first step in developing longterm community engagement strategies. The results of the research are showing, among other things, that the inhabitants of modern Soba already have a variety of experiences with archaeological remains due to house construction in the area of historical monuments. Almost all interviewees confirmed that they had some kind of contact with the monuments; they knew how to recognize local archaeological artifacts, but they assigned Christian origins to all of them. Generally, Past Soba is perceived as a Christian city, ruled by Anaj-extraordinary tall African people (the myth of the Anaj is well known in communities living in Northern and Central Sudan and is often associated with archaeological sites [Bradshaw, 2017, p.163]). The information that it was a multiethnic metropolis and that one of the districts was to be inhabited by Prophet Muhammad's followers was received with surprise or disbelief.

The digging of house foundations and the excavation of wells and toilets are the most common circumstances in which spontaneous discoveries occur. Archaeological findings also occur during the rainy seasons, especially due to devastating floods (like the one in 2013). The interviewees were generally aware of the original size of the area where the archaeological remains can be found in large quantities. This area goes beyond the boundaries of today's archaeological zone and includes lands that are entirely built-up, such as the farms and the housing districts of Gen `ab and Marabiya al-Sherif (east of the main tarmac road). What is the attitude of the inhabitants to the archaeological remains? When found during house construction, the tendency is to dispose of them discreetly. Bones and most ceramics are discarded in the nearby wadi (called Al-Khor) or in informal dumps. As such, the artifacts are treated as waste. It is worth adding that the owners of several houses in the vicinity of Al-Khor mentioned they came across graves during construction works, indicating the presence of a cemetery in this area (Fig. 2). In the conversations about artifacts and the archaeological site, the residents expressed the fear of being dispossessed of the land and everything that is built on it. At the same time, stories about the archaeological remains are a part of the history of every household and are eagerly discussed. The finds were not always disposed of, at least not all of them. The characteristic large red bricks are still widely recognized today, especially in the nearby cemeteries where they are used to cover graves and as tombstones (e.g., Sheikh Wad Taraf cemetery). These so-called "Christian bricks" are often a subject of discussion. The inhabitants of Modern Soba consider them to be a highly symbolic artifact of the Past Soba.

In the past centuries, Soba was a reservoir of building materials. Karl Richard Lepsius, who visited the place in the 1840 s, saw piles of red bricks from nearby ruins ready to be loaded on the river bank. They were to be used in the construction of Khartoum (Lepsius, 1853, p. 162-163; 1913/V, p. 347). The Soba residents implied that the looters were the colonizers (representatives of the 


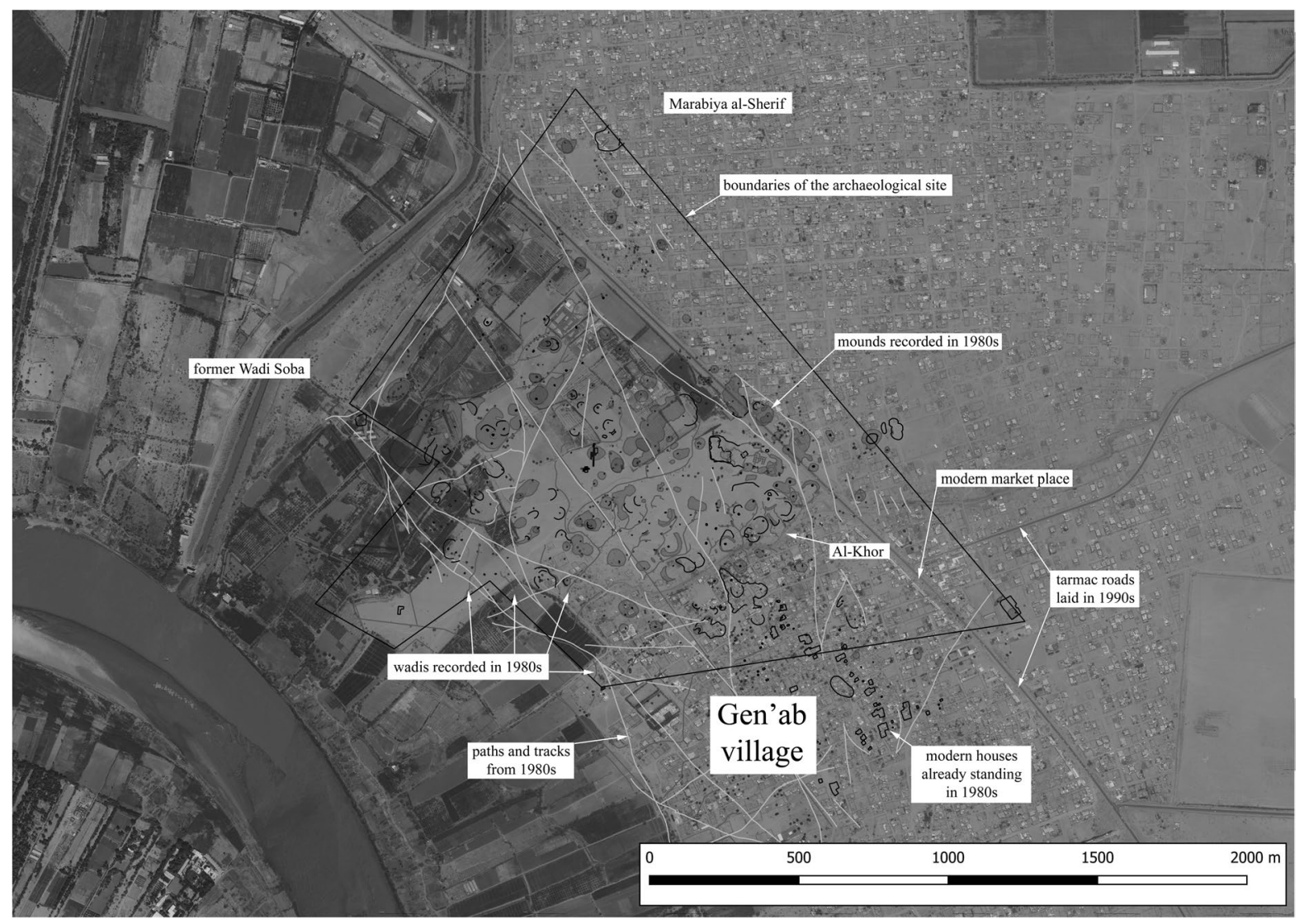

Fig. 2 Plan of the site made in the 1980s (the SARS Archive in the British Museum) against the satellite image from 2015 (Bing Maps)

Turco-Egyptian and Anglo-Egyptian Sudan), the authorities of independent Sudan, and the archaeologists working here since the beginning of the twentieth century. They consider themselves as the ones whose cultural heritage is always looted.

In some houses, medieval objects are brought back to life, mainly because of their similarity with the equipment still used in the countryside. This is the case, for example, of various sizes of grinderssuch as the so-called murhaga. These objects are still essential kitchen utensils in many houses. The interviewees-mainly women-claimed that they bring to mind their family home before they moved to Soba. To some of them, these artifacts "speak" to the legacy of past generations or proof of the specificity of the people who once lived there. Ceramic vessels, especially those with painted decorations, also attract attention. Larger and smaller painted pottery sherds are treated as objects of aesthetic value. They are sometimes exhibited in the living room or the yard.

The representatives of elite groups (former traditional leaders and intellectuals) and the inhabitants who settled in Soba before the 1990s (Mugarba Arabs-MacMichael, 1922, I, p. 318) often treat the site as a source of cultural pride. The reason behind this is that Modern Soba lies in the location of the former capital of the medieval kingdom. The artifacts are evidence of the power and wealth of the people who once lived there. They are "objects of memory," to use Pierra Nora's (2009) terminology. Painted ceramics, large burnt bricks, and various everyday objects are all heterogeneous symbols, silent testimonies of the past, which appeal to many contemporary people of Soba. Rebecca Bradshaw's (2017) study reveals the great importance of material culture in defining the traditional way of life. According to the interviewees, the former inhabitants of Soba used 
almost the same objects (querns, millstones, large stocked dishes, etc.) as the people of central Sudan did in the present day or recent memory. This attitude contributes to the interviewees' sense of identity and connection to their heritage.

The changes brought to the archaeological landscape by the new settlement and urbanization have led to a crisis. This crisis is well illustrated in the stories about the "cursed house" (beit maskun), several of which were gathered during conversations with residents of Gen`ab area. One particular house, located near Al-Khor, was often mentioned. All neighbors confirmed its sinister character. People connected it with various paranormal events: the feeling of being close to some invisible creature, strange sounds, the cry of a child, the levitation of objects, and the presence of various reptiles unfriendly to humans. A large tree once stood in the location of the house. It was old and partially dried out. It is said that the house owner cut it down and erected his home on the spot. However, he did not enjoy it for long. After a few days, he left and never returned. It was said that it was difficult to live in the house. However, the house is not uninhabited.

The motif of an old tree as the habitat of a mischievous spirit can be found in the folklore of the whole of central Sudan (e.g., Chataway, 1930, p. 248). This is not a cult referring to some chosen tree specimen and its animation, but the sacred power hidden in the tree (Bradshaw, 2017, p. 174). These kinds of stories can have different roles and can be heard in various regions of North Africa (e.g., Glazier, 2003). Until recently, most of the study area was customarily forbidden and associated with the metaphysical world. The custom says that the peace of the past people represented by the archaeological remains must not be disturbed. Nothing should be taken from there or built there. In Soba's case, demographic pressure is becoming more intense. New migrants build on former ruins, seizing larger and larger areas of the site (despite the disapproval of the incumbent residents, who ironically once did the same). Stories of hostile, supernatural forces can be the aftermath of breaking the traditional taboo. However, the price does not seem to be too high. According to the interviewees, the supernatural punishment only affects those who have broken some taboos, such as cutting down a tree or killing an animal, the local guardian spirit. Such stories can give comfort and be a form of negotiation with the spiritual world.

\section{Archaeological and Geophysical Investigations}

Ancient Graves and Cemeteries in Archaeological Research

Since the beginning of scientific research at Soba, no clearly defined funerary zone has been identified. Some burials have been found at various locations all over the site, exhibiting a large diversity in funerary provisions. Small concentrations of graves were located close to the churches at the site, all furnished in a typically Christian fashion. Some were relatively modest, such as the ones at a small cemetery to the south of Church $\mathrm{C}$ in the western part of the site (Fig. 3), where deceased individuals were interred in simple pits with no accompanying structures (Shinnie, 1955, p. 26). Numerous burials at the cemetery adjacent to Building $\mathrm{G}$ at Mound $\mathrm{Z}$ have rectangular monuments, constructed either of sun-dried or fired bricks (Welsby, 1998, p. 49-50). The outer surfaces were often rendered with mortar and whitewashed. Selected individuals were placed in subterranean vaulted chambers (Abdel Rahman, 2000, p. 27; Welsby, 1998, p. 56). A significant cluster of graves was also found next to Building A at Mound B, the most prominent church at the site, along with a crypt housing the remains of multiple individuals (Welsby, 1998, p. 55).

While most of the interments seem to have been aligned along the E-W axis with the head of the deceased to the west, some individuals were placed in the grave on either the left or right side, sometimes in a contracted position, or even ventrally (Welsby \& Daniels, 1991, p. 26). Among the latter are several isolated graves deposited in simple grave cuts, following different orientations and burial manners, and devoid of almost any grave goods (except occasional beads or pottery). They also lack any traits about the occupants' religious persuasion or cultural background. British researchers who uncovered a significant number of such graves suspected they might have belonged to non-Christians and noticed some similarities to Funj-era burials at Abu Geili and Jebel Moya (Welsby \& Daniels, 1991, p. 26). 
Fig. 3 Satellite imagery (Bing Maps) of the archaeological site at Soba, showing the location of the area covered with the geophysical survey (black, bold line), main mounds (black, bold capital letters), and the trenches (white, capital letters) opened in 2019-2020 (prepared by Mariusz Drzewiecki)

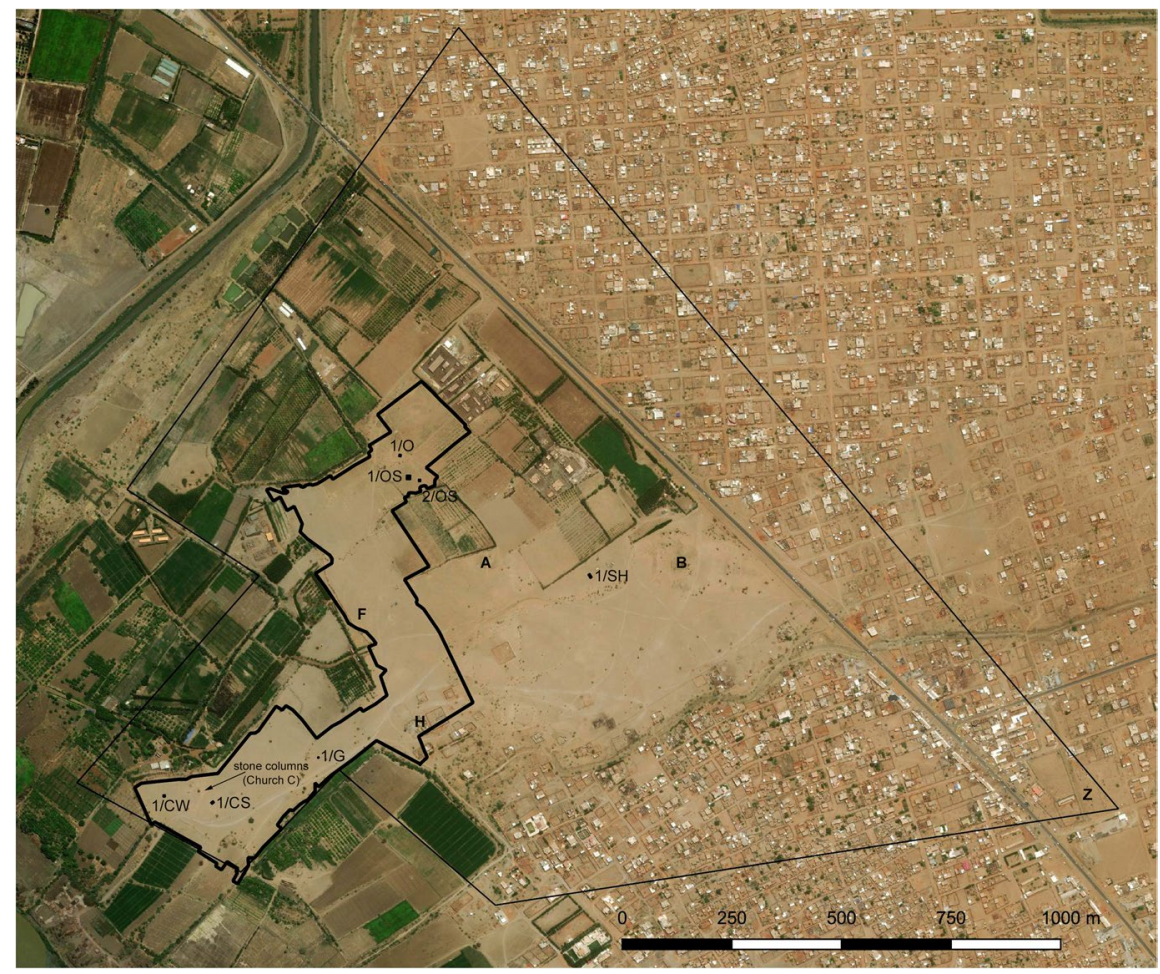

During archaeological fieldwork at Soba in the 2019-2020 season, 23 burials were discovered at Mound OS (Fig. 4). All burials were interred in simple oval pits, with no accompanying funerary structures. According to the common Christian practice (Welsby, 2002, p. 48-61), most deceased were aligned along the E-W axis with their heads to the west. While some remains were placed extended supine, others rest on either the right or left side, or facing down. At least two burials (graves 13 and 14) follow the N-S orientation instead of E-W (Fig. 5). Some of the deceased must have been wrapped in shrouds or buried in clothing, as tiny pieces of dark brown coarsely woven fabric were recorded next to the remains. Large fragments of a globular cooking pot were employed to protect the head and pelvis of an adult woman buried in grave 16 in the northern part of Trench 1/OS (Fig. 6). The practice of protecting the head of the deceased was widespread in Medieval Nubia (Welsby, 2002, p. 49). However, head protection was usually made with two or three bricks placed around the head. Such protective measures were recorded at other parts of the site (Shinnie, 1955, p. 26; Welsby, 1998, p. 51, 54-55; Welsby \& Daniels, 1991, p. 122), but not at any of the burials at Mound OS. The use of pottery sherds for that purpose is relatively rare but not unprecedented (Ciesielska et al., 2018). The heterogeneity of burial manners places the cemetery at Mound OS in line with previously recorded interments of doubtful cultural and religious affinity. Radiocarbon dating from the fill of two graves (nos. 15 and 16) provided terminus post quem dates of the ninth and tenth centuries $\mathrm{AD}$, well within the period of Christian faith dominance in the region (details of all radiocarbon dates are given in Table 1).

Soon after the inception of the Alwa kingdom in the sixth century, the seat of power adopted Christianity. The changes in traditional beliefs and cultural practices must have been a prolonged process. The change in burial practices has often been considered one of the initial markers of transition to the Christian way of life in Nubia at the end of the fifth century. However, as more and more archaeological material comes to light, it becomes clearer that while new influences appear on the stage, a continuity of certain practices and gradual transformation of others can be observed. Early converts continued to follow African religious practices and gradually 


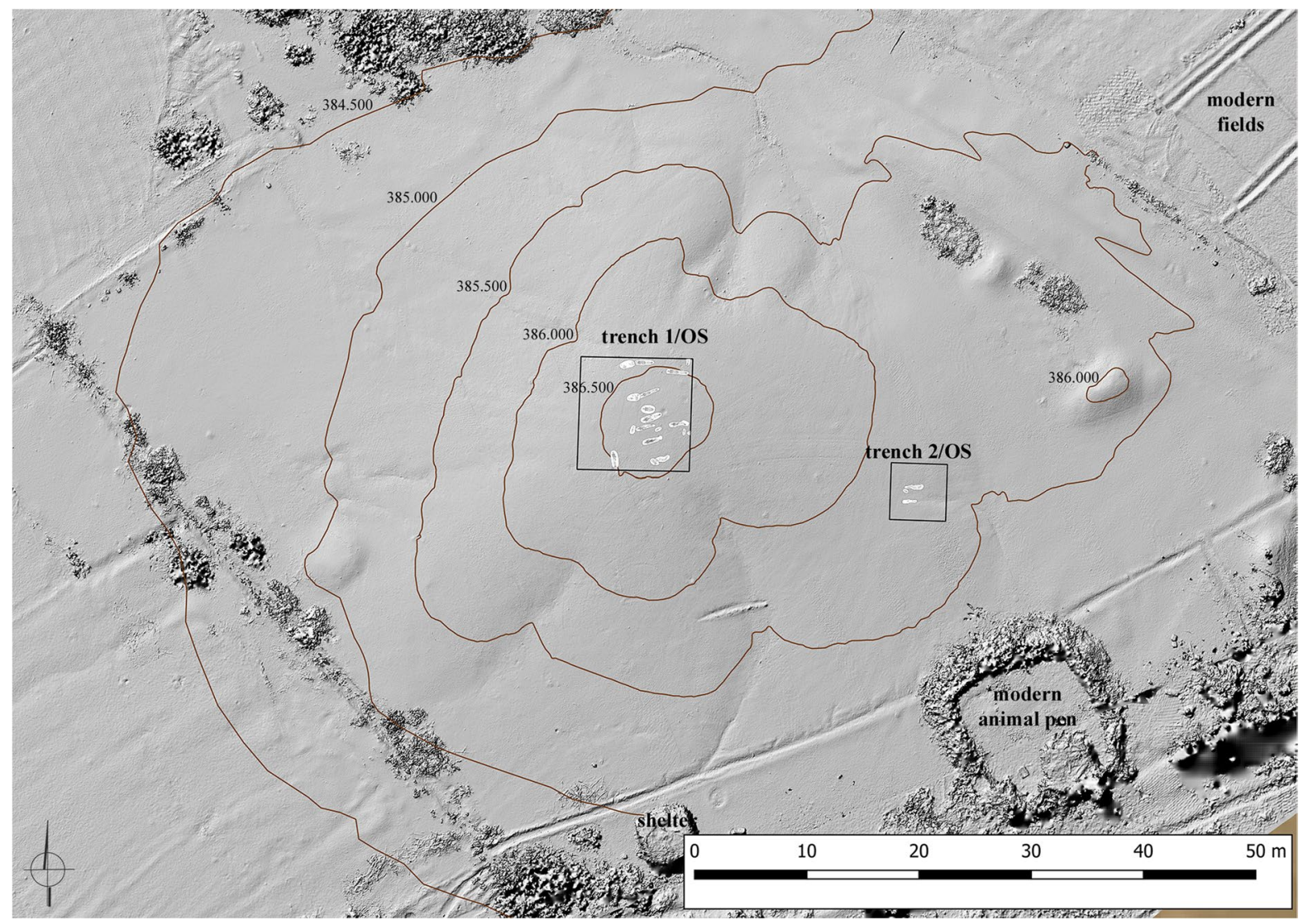

Fig. 4 Cemetery on Mound OS, with background image DEM created in 2019 (prepared by Joanna Ciesielska and Mariusz Drzewiecki)

turned toward new, distinctively Christian practices or modifications (Volp, 2002, p. 269).

Furthermore, written sources report that Soba was a truly cosmopolitan city (Vantini, 1975, 613). Situated close to the confluence of the White Nile and the Blue Nile, at a crossroads of the major routes connecting Ethiopia and the Red Sea, Kordofan and Darfur peoples, Eastern desert peoples, and the entire extent of the Nile valley, the city was probably a mosaic of cultures and ethnicities, especially due to its engagement in trade networks. A treaty between the kingdom of Makuria and the Umayyad Caliphate, the so-called Baqt, which lasted for centuries, restricted Arabs from crossing into Nubia under Makurian control (Seignobos, 2016, p. 44). However, Alwa was not a signatory of the Baqt, and thus, a gradual influx of Arab culture and Islam probably added to the diversity of the local population.
Based on the archaeological record and preliminary results of ethnoarchaeological research launched within the framework of the current project, graves have now been found all over the site rather than being restricted to clearly defined burial grounds. The heterogeneity of burial practices attests to the cultural and religious diversity of the inhabitants of Soba. In the Mediterranean, at least until the fourth century AD, Christians and practitioners of other religions were still buried within the same burial grounds (Rebillard, 2009, p. 34). In fact, there were no clear regulations against mixing Christians and non-Christians in cemeteries during the Late Antiquity (Rebillard, 2013, p. 229-232). As far as one can tell, based on currently available research, new tombs, constructed according to the new ideology, were placed next to earlier, Meroitic and Post-Meroitic burials in Nubia. Multiple instances of Christian tombs situated in earlier burial grounds were found all over Lower 


\section{Trench 1/OS}

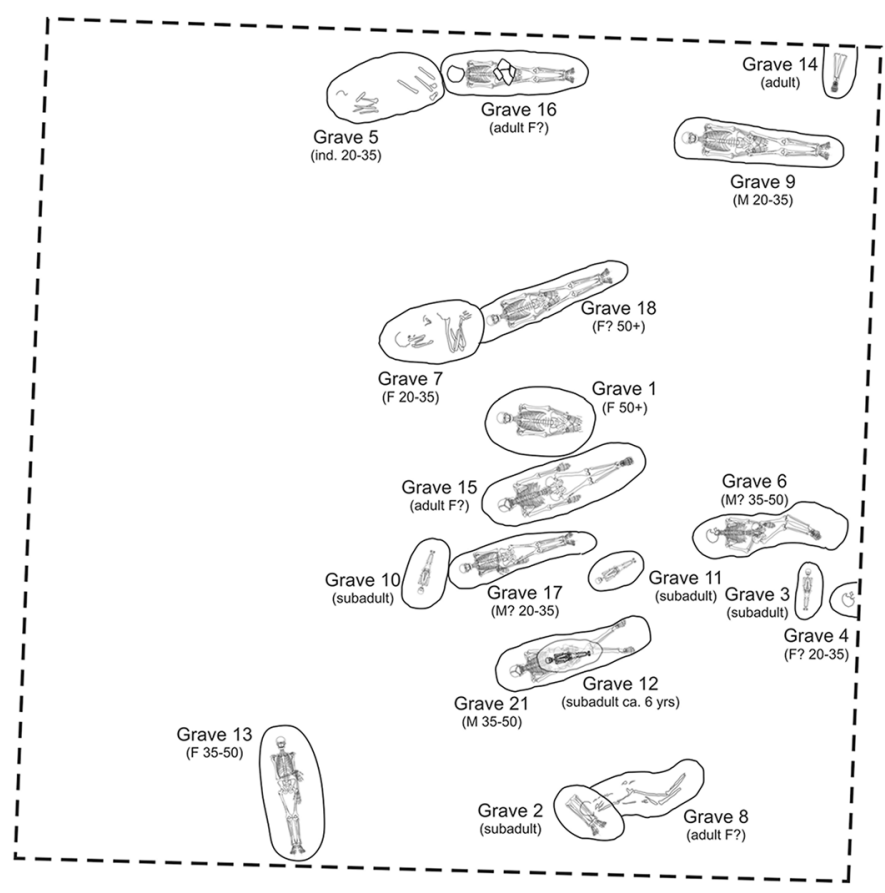

Trench 2/OS

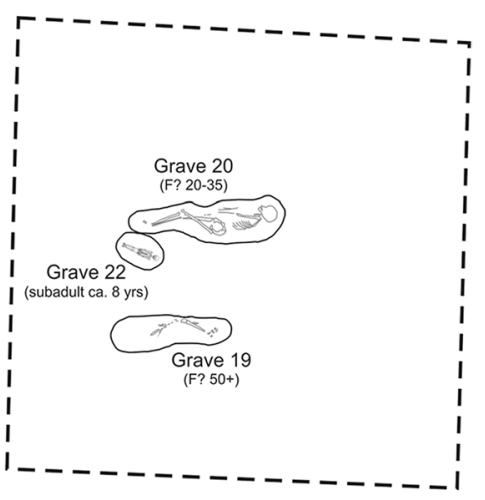

Fig. 5 A detailed plan of burials excavated at Mound OS (prepared by Joanna Ciesielska)

Fig. 6 Grave 16 on Mound OS (photo by Joanna Ciesielska)

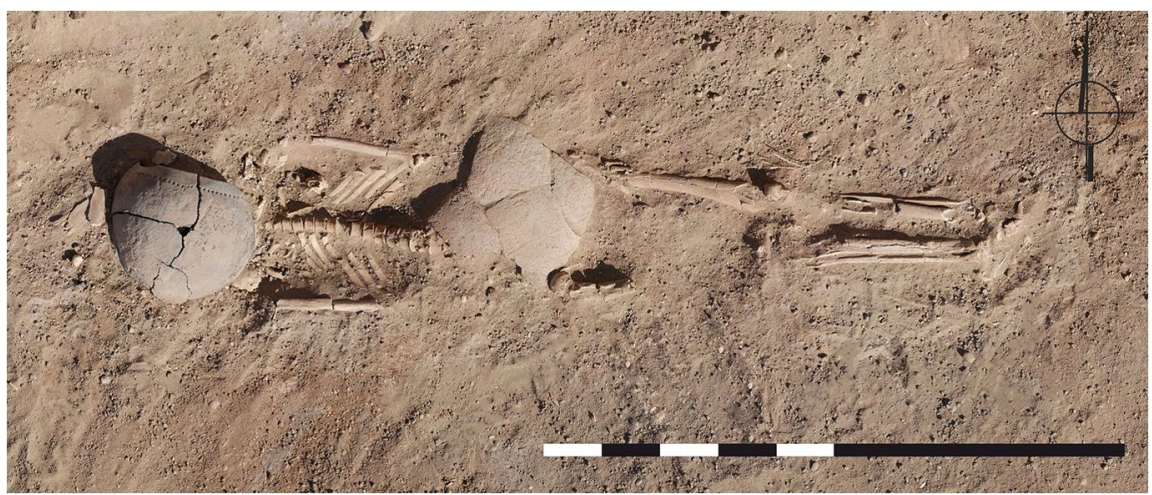

Nubia (e.g., Reisner, 1910, p. 345; Rilly \& Francigny, 2011), in the Fourth Cataract region (Welsby, 2005, p. 5), and even in the vicinity of Meroe (Lenoble, 1987).

The city's enormous physical size and population suggest that large-scale cemeteries must have existed, though they are yet to be found. The presence of culturally diverse interments in various locations all over the site attests to the dynamics of a multiethnic society and the reuse of sites with little consideration for religious persuasion or cultural affinity. In trench $1 /$ SH (see Fig. 3), a unique discovery was made. Below 
Table 1 Radiocarbon dates from samples collected in 2019-2020. Processed in Poznań Radiocarbon Laboratory (Calibration made with OxCal v4.4.2, IntCal 20, r.5 by Mariusz Drzewiecki)

\begin{tabular}{|c|c|c|c|c|c|}
\hline Laboratory reference & Sample inv no & Sample location & Radiocarbon age BP & $68.2 \%$ probability & $95.4 \%$ probability \\
\hline Poz-122446 & $\begin{array}{l}\text { SOBA_2020_SH1_ } \\
\text { s086 }\end{array}$ & $\begin{array}{l}\text { Trench 1/SH } \\
\text { phase: before erec- } \\
\text { tion of mud-brick } \\
\text { architecture; last } \\
\text { phase of timber } \\
\text { architecture }\end{array}$ & $995 \pm 30$ & $\begin{array}{l}\text { 994AD }(57.8 \%) \\
\text { 1043AD } \\
\text { 1105AD (10.4\%) } \\
\text { 1118AD }\end{array}$ & $\begin{array}{l}\text { 986AD }(63.8 \%) \\
\text { 1052AD } \\
\text { 1081AD }(31.6 \%) \\
\text { 1153AD }\end{array}$ \\
\hline Poz-122448 & $\begin{array}{l}\text { SOBA_2020_SH1_ } \\
\text { s091 }\end{array}$ & $\begin{array}{l}\text { Trench } 1 / \mathrm{SH} \\
\text { phase: short before } \\
\text { erection of timber } \\
\text { architecture }\end{array}$ & $1090 \pm 30$ & $\begin{array}{l}\text { 899AD }(24.2 \%) \\
\text { 924AD } \\
\text { 945AD }(44.0 \%) \\
\text { 990AD }\end{array}$ & $\begin{array}{l}\text { 892AD }(95.4 \%) \\
\text { 1014AD }\end{array}$ \\
\hline Poz-122449 & $\begin{array}{l}\text { SOBA_2020_CS1_ } \\
\text { s152 }\end{array}$ & $\begin{array}{l}\text { Trench 1/CS } \\
\text { phase: after } \\
\text { construction of } \\
\text { walking level } \\
\text { (last discovered in } \\
\text { trench) }\end{array}$ & $1250 \pm 30$ & $\begin{array}{l}\text { 687AD }(68.2 \%) \\
\text { 775AD }\end{array}$ & $\begin{array}{l}\text { 676AD }(74.8 \%) \\
\text { 779AD } \\
\text { 790AD }(20.6 \%) \\
\text { 870AD }\end{array}$ \\
\hline Poz-122450 & $\begin{array}{l}\text { SOBA_2020_CS1_ } \\
\text { s153 }\end{array}$ & $\begin{array}{l}\text { Trench 1/CS } \\
\text { phase ?: before } \\
\text { construction of } \\
\text { walking level } \\
\text { (last discovered } \\
\text { in trench)+erec- } \\
\text { tion of mud brick } \\
\text { construction }\end{array}$ & $1190 \pm 30$ & $\begin{array}{l}\text { 778AD }(11.0 \%) \\
\text { 793AD } \\
\text { 800AD }(57.2 \%) \\
\text { 878AD }\end{array}$ & $\begin{array}{l}\text { 722AD }(2.9 \%) \\
\text { 740AD } \\
\text { 766AD }(89.0 \%) \\
\text { 899AD } \\
\text { 924AD }(3.5 \%) \\
\text { 945AD }\end{array}$ \\
\hline Poz-122451 & $\begin{array}{l}\text { SOBA_2020_CW1_ } \\
\text { s154 }\end{array}$ & $\begin{array}{l}\text { Trench } 1 / \mathrm{CW} \\
\text { phase: short before } \\
\text { construction N-S } \\
\text { oriented mud brick } \\
\text { architecture- wall } \\
\text { no. } 31 \text {; third occu- } \\
\text { pational phase) }\end{array}$ & $1095 \pm 30$ & $\begin{array}{l}\text { 899AD }(25.7 \%) \\
\text { 924AD } \\
\text { 945AD }(42.5 \%) \\
\text { 987AD }\end{array}$ & $\begin{array}{l}\text { 890AD }(95.4 \%) \\
\text { 1013AD }\end{array}$ \\
\hline Poz-123461 & $\begin{array}{l}\text { SOBA_2020_CW1_ } \\
\text { a158 }\end{array}$ & $\begin{array}{l}\text { Trench 1/CW } \\
\text { phase: short before } \\
\text { construction wall } \\
\text { no. 33, part of } \\
\text { NE-SW ori- } \\
\text { ented mud-brick } \\
\text { architecture; first } \\
\text { occupational phase }\end{array}$ & $1515 \pm 30$ & $\begin{array}{l}\text { 474AD }(5.6 \%) \\
\text { 485AD } \\
\text { 536AD }(62.6 \%) \\
\text { 600AD }\end{array}$ & $\begin{array}{l}\text { 428AD }(24.6 \%) \\
\text { 495AD } \\
\text { 507AD }(2.1 \%) \\
\text { 520AD } \\
\text { 527AD }(68.6 \%) \\
\text { 615AD }\end{array}$ \\
\hline Poz-122452 & $\begin{array}{l}\text { SOBA_2019_OS1_ } \\
\text { s078 }\end{array}$ & $\begin{array}{l}\text { Trench } 1 / \mathrm{OS} \\
\text { phases: shortly after } \\
\text { finish of intensive } \\
\text { use of central } \\
\text { feature }\end{array}$ & $1135 \pm 30$ & $\begin{array}{l}\text { 885AD }(68.2 \%) \\
\text { 969AD }\end{array}$ & $\begin{array}{l}\text { 777AD }(4.3 \%) \\
\text { 792AD } \\
\text { 803AD }(8.0 \%) \\
\text { 844AD } \\
\text { 857AD }(83.0 \%) \\
\text { 986AD }\end{array}$ \\
\hline Poz-123460 & $\begin{array}{l}\text { SOBA_2019_OS1_ } \\
\text { s077 }\end{array}$ & $\begin{array}{l}\text { Trench } 1 / \mathrm{OS} \\
\text { phase: (first occu- } \\
\text { pational phase, } \\
\text { shortly before erec- } \\
\text { tion of wall E) }\end{array}$ & $1450 \pm 30$ & $\begin{array}{l}\text { 592AD }(68.2 \%) \\
\text { 643AD }\end{array}$ & $\begin{array}{l}\text { 561AD }(95.4 \%) \\
\text { 651AD }\end{array}$ \\
\hline
\end{tabular}


Table 1 (continued)

\begin{tabular}{|c|c|c|c|c|c|}
\hline Laboratory reference & Sample inv no & Sample location & Radiocarbon age BP & $68.2 \%$ probability & $95.4 \%$ probability \\
\hline Poz-122453 & $\begin{array}{l}\text { SOBA_2019_OS1_ } \\
\text { s076 }\end{array}$ & $\begin{array}{l}\text { Trench 1/OS } \\
\text { phase: second } \\
\text { occupationalphase; } \\
\text { shortly before con- } \\
\text { struction of wall S, } \\
\text { and probably the } \\
\text { erection of whole } \\
\text { central feature }\end{array}$ & $1070 \pm 30$ & $\begin{array}{l}\text { 905AD }(9.4 \%) \\
\text { 916AD } \\
\text { 968AD }(58.8 \%) \\
1016 \mathrm{AD}\end{array}$ & $\begin{array}{l}\text { 895AD }(20.9 \%) \\
\text { 928AD } \\
\text { 940AD }(74.5 \%) \\
1021 \mathrm{AD}\end{array}$ \\
\hline Poz-122455 & $\begin{array}{l}\text { SOBA_2019_O1_ } \\
\text { s074 }\end{array}$ & $\begin{array}{l}\text { trench } 1 / O \text { phase: } \\
\text { after abandonment } \\
\text { of church }\end{array}$ & $780+/-30$ & $\begin{array}{l}\text { 1224AD }(68.2 \%) \\
\text { 1270AD }\end{array}$ & $\begin{array}{l}\text { 1210AD }(95.4 \%) \\
1281 \mathrm{AD}\end{array}$ \\
\hline Poz-122474 & $\begin{array}{l}\text { SOBA_2019_O1_ } \\
\text { s073 }\end{array}$ & $\begin{array}{l}\text { trench } 1 / O \text { phase: } \\
\text { before construction } \\
\text { of the church }\end{array}$ & $1160+/-30$ & $\begin{array}{l}\text { 778AD }(9.1 \%) \\
\text { 791AD 804AD } \\
(20.4 \%) 842 \mathrm{AD} \\
\text { 860AD }(26.1 \%) \\
\text { 898AD 925AD } \\
(12.7 \%) 944 \mathrm{AD}\end{array}$ & $\begin{array}{l}\text { 773AD }(71.8 \%) \\
\text { 906AD 916AD } \\
(23.6 \%) 968 \mathrm{AD}\end{array}$ \\
\hline Poz-122456 & $\begin{array}{l}\text { Poz-122456 } \\
\text { SOBA_2019_OS2_- } \\
\text { s072 }\end{array}$ & $\begin{array}{l}\text { trench } 2 / \mathrm{OS} \\
\text { phase:shortly } \\
\text { before formation of } \\
\text { lime layer }\end{array}$ & $930+/-30$ & $\begin{array}{l}\text { 1041AD }(12.6 \%) \\
\text { 1059AD 1064AD } \\
(28.5 \%) \text { 1109AD } \\
\text { 1116AD }(27.2 \%) \\
\text { 1154AD }\end{array}$ & $\begin{array}{l}\text { 1025AD }(95.4 \%) \\
1165 \mathrm{AD}\end{array}$ \\
\hline Poz-122454 & $\begin{array}{l}\text { SOBA_2019_OS2_ } \\
\text { s070 }\end{array}$ & $\begin{array}{l}\text { trench 2/OS phase: } \\
\text { after formation of } \\
\text { lime layer }\end{array}$ & $1110+/-30$ & $\begin{array}{l}\text { 895AD }(32.7 \%) \\
\text { 928AD 940AD } \\
(35.5 \%) 976 \mathrm{AD}\end{array}$ & $\begin{array}{l}\text { 879AD }(95.4 \%) \\
1013 \mathrm{AD}\end{array}$ \\
\hline Poz-122727 & $\begin{array}{l}\text { SOBA_2019_OS1_ } \\
\text { s037 }\end{array}$ & $\begin{array}{l}\text { trench } 1 / \mathrm{OS} \text { phase: } \\
\text { functioning of } \\
\text { cemetery (grave } \\
\text { no 15) }\end{array}$ & $1055+/-30$ & $\begin{array}{l}\text { 973AD }(68.2 \%) \\
\text { 1020AD }\end{array}$ & $\begin{array}{l}\text { 898AD }(11.5 \%) \\
\text { 924AD 944AD } \\
(83.9 \%) \\
1025 \mathrm{AD}\end{array}$ \\
\hline Poz-122458 & $\begin{array}{l}\text { SOBA_2019_OS1_ } \\
\text { s021 }\end{array}$ & $\begin{array}{l}\text { trench } 1 / \mathrm{OS} \text { phase } \\
\text { :functioning of } \\
\text { cemetery (grave } \\
\text { no 16) }\end{array}$ & $1200+/-30$ & $\begin{array}{l}\text { 775AD }(3.4 \%) \\
\text { 779AD 788AD } \\
(64.8 \%) 873 \mathrm{AD}\end{array}$ & $\begin{array}{l}\text { 715AD }(6.2 \%) \\
\text { 744AD 765AD } \\
\text { (87.8\%) 895AD } \\
\text { 928AD }(1.4 \%) \\
\text { 940AD }\end{array}$ \\
\hline
\end{tabular}

the extensive remains of medieval occupation is a much older burial with only skeletal remains in a small oval pit, placed in a contracted position on the right side. The pit was carved into the bedrock. The burial was about $40 \mathrm{~cm}$ below the oldest medieval remains discovered in the trench. The layer dividing the burial from the medieval remains consisted of densely packed gravel which appears to be the natural soil. It seems that the hiatus between the burial and medieval occupation must have been very long. The positioning of the internment is similar to those of the Mesolithic and Neolithic graves in the region. However, no dating material was obtained from the grave.
Large-Scale Geophysical Survey and Excavations

The geophysical survey of Soba provided a large volume of data on archaeological features; however, identification of graves was not possible. The reason was that none of the graves recorded during the 2019-2020 excavations had superstructures, nor any distinguishable grave fills. They were located among architectural remains which created much stronger anomalies, dominating the readings.

Methods

For noninvasive recognition of the spatial organization of the site, a fluxgate magnetometer was used, 
which permits obtaining data in high resolution in the relatively short time needed to carry out the survey. The sampling density was $0.25 \mathrm{~m}$ along profiles set $0.5 \mathrm{~m}$ apart, measured in parallel mode within $20-\mathrm{x}-20$-m grids. Such a setup of acquisition parameters is considered standard procedure, allowing for the recognition of the archaeological potential of the investigated site, the determination of the location of archaeological structures, and the analysis of the shape and nature of individual anomalies (Schmidt et al., 2015, p. 64). On the selected parts of the site, a pilot study was conducted with ground-penetrating radar (GPR) prospection, which provided further details and information on the depth and stratigraphic relationships of the preserved structures. The Mala GX HDR Ground Penetrating Radar System equipped with a $450-\mathrm{MHz}$ shielded antenna was used. The measurements were carried out along parallel profiles $0.5 \mathrm{~m}$ apart. Within the profiles, data was collected at $0.025 \mathrm{~m}$ intervals.

The magnetic survey provided a detailed map of the geophysical response of subsurface structures (Drzewiecki et al., 2020). The anomaly classification was based on both archaeological records and theoretical foundations of archaeological geophysics. Therefore, the interpretation was based primarily on the analysis of the shape of the magnetic features and the analysis of the intensity, amplitude, and distribution of the magnetic anomalies. The geophysical map (Fig. 7) shows the interpretation of the results obtained from the magnetic survey at Soba in 2019-2020. In addition to the geophysical survey, seven small test trenches were opened (see Fig. 3). Although the study area was limited, it gave a better understanding of the geophysical results. The location of trenches in various parts of the Soba site (mounds and areas $\mathrm{O}, \mathrm{OS}, \mathrm{SH}, \mathrm{CS}, \mathrm{CW}$, and $\mathrm{G}$-names are based on Welsby \& Daniels, 1991; Fig. 1) and the results of radiocarbon dating have brought new information on the spatial development of the capital.

\section{Results}

The archaeological interpretation of the geophysical results allowed us to distinguish the characteristic urban features, including the remains of walls and entire buildings erected from mud and red bricks, and identify the presence of furnaces and kilns, heavily burned structures, and layers of ash.

\section{Red-Brick Mounds}

The areas with fired brick rubble on the surface were recorded on the magnetic map as high-amplitude noise, making it impossible to identify any well-preserved structures below. The case was visible in 5-x5-m trench 1/O located on Mound O, covered with red-brick debris. On the magnetic map, the area was marked with a strong reading of the surface materials and had no signs of the architectural remains below. Red-brick mounds have been a target of brick extraction in the past (Welsby, 1998, p. 17-18); thus, the architecture in such places can be heavily damaged and had mixed materials. In trench $1 / \mathrm{O}$, small fragments of a red-brick floor with faint traces of occupation above and below were discovered, making it possible to determine the absolute chronology of the feature. Radiocarbon dates from a sample taken from under the brick floor show that the floor was built after AD 773-906 (with 72\% probability). Because no traces of walls were found, it was impossible to distinguish the specific construction phases that this building may have undergone. However, the radiocarbon date obtained from the layer located above the brick floor gave a date of AD 1210-1281 (95\%), the period of the general decline of the town. Other layers (except for one walking level) in the trench were mixed and contained red-brick debris, creating magnetic noise that obscures the identification of the brick floor remains in the survey.

\section{Mud-Brick Architecture}

In trench $1 / \mathrm{OS}$, located at the top of a gravel hill, a complex of regular N-S and E-W oriented mud-brick walls were discovered. Excavations conducted in a central room (feature 17) yielded radiocarbon dates suggesting that the mud-brick construction took place after AD 561-651 (95\%). For around 300 years after that, the area west of the eastern wall was probably an outdoor space. In the next short phase, other walls were constructed, and the area was covered with a roof resting on palm logs (a negative of one log was recorded in debris filling of the room). Radiocarbon dates from the layer below the southern wall of feature 17 suggest that the wall was built after $A D$ 
Fig. 7 Interpretation of the geophysical data (prepared by Robert Ryndziewicz)

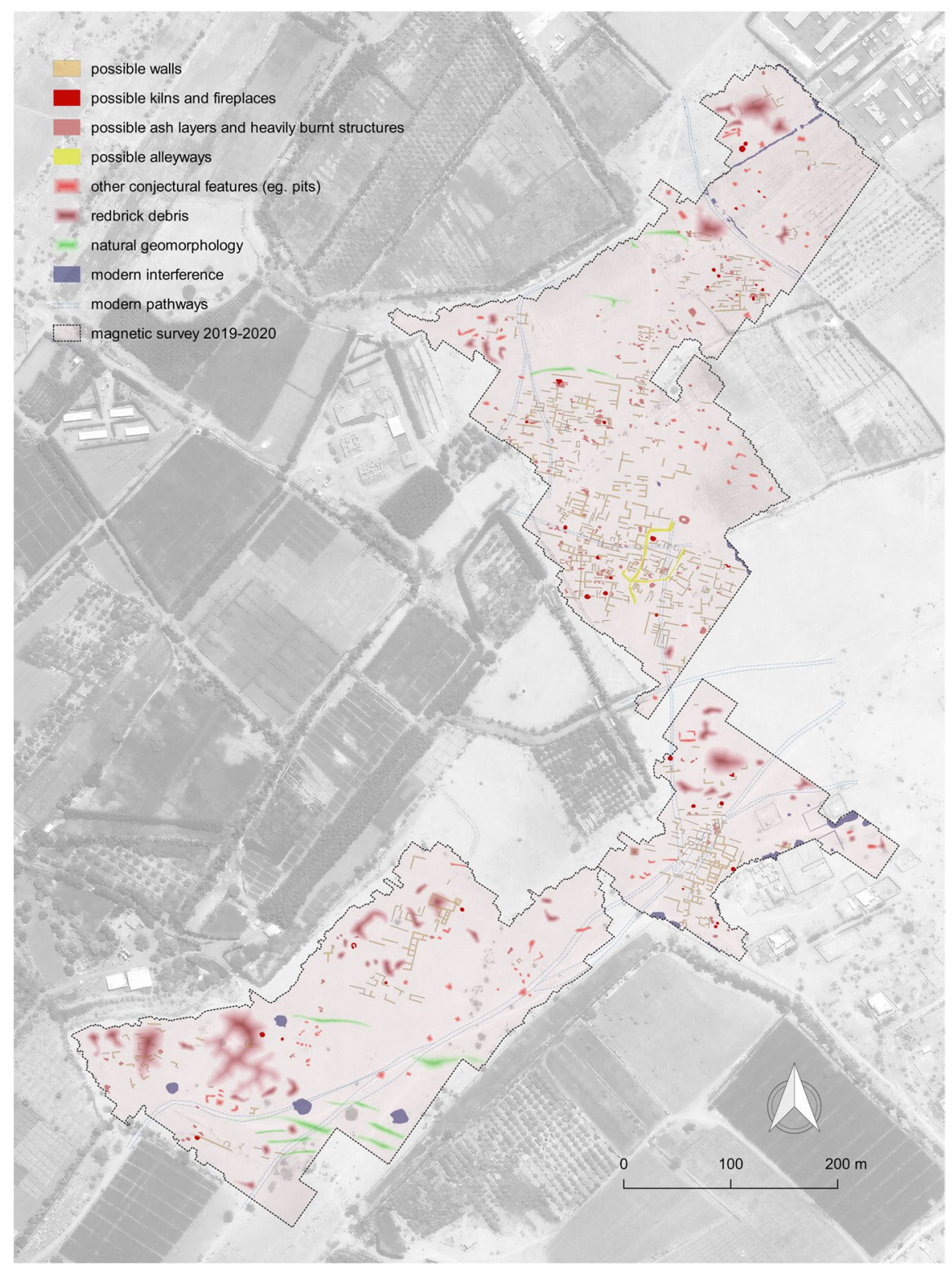

940-1021 (74.5\%). Radiocarbon dates from a layer related to the use of feature 17 indicate that the building existed in AD 857-986 (83\%). The area became a burial ground in the second half of the tenth century $\mathrm{AD}$, with some of the grave pits cutting through the remains of the mud-brick walls (see Table 1; Fig. 8).

The magnetic survey recorded complete and extensive remnants of urban structures in the OS, FN, F, and HW areas, giving a glimpse of the density of buildings in the medieval capital. Only a few anomalies interpreted as walls have a different orientation, which may be a clue to distinguishing changes in the settlement pattern. Trench $1 / \mathrm{CW}$ (west of Church $\mathrm{C}$; see Fig. 3) was located on one of the low mounds where magnetic survey indicated the presence of walls in both orientations - true north and slightly off north. It was expected that the dig would be approximately one meter deep since the mound was approximately $0.8 \mathrm{~m}$ high. To our surprise, at the level where we were expecting to find virgin soil, well-preserved NE-SW-oriented mud-brick architecture appeared. Due to time restrictions, we were not able to reach the virgin soil level in that trench and had to stop excavations $1.54 \mathrm{~m}$ below the surface (Fig. 9, top right). 
Fig. 8 Trench 1/OS after the end of excavations, showing feature 17 in the center; white dashed lines indicate the location of the grave pits (prepared by Tomasz Michalik)

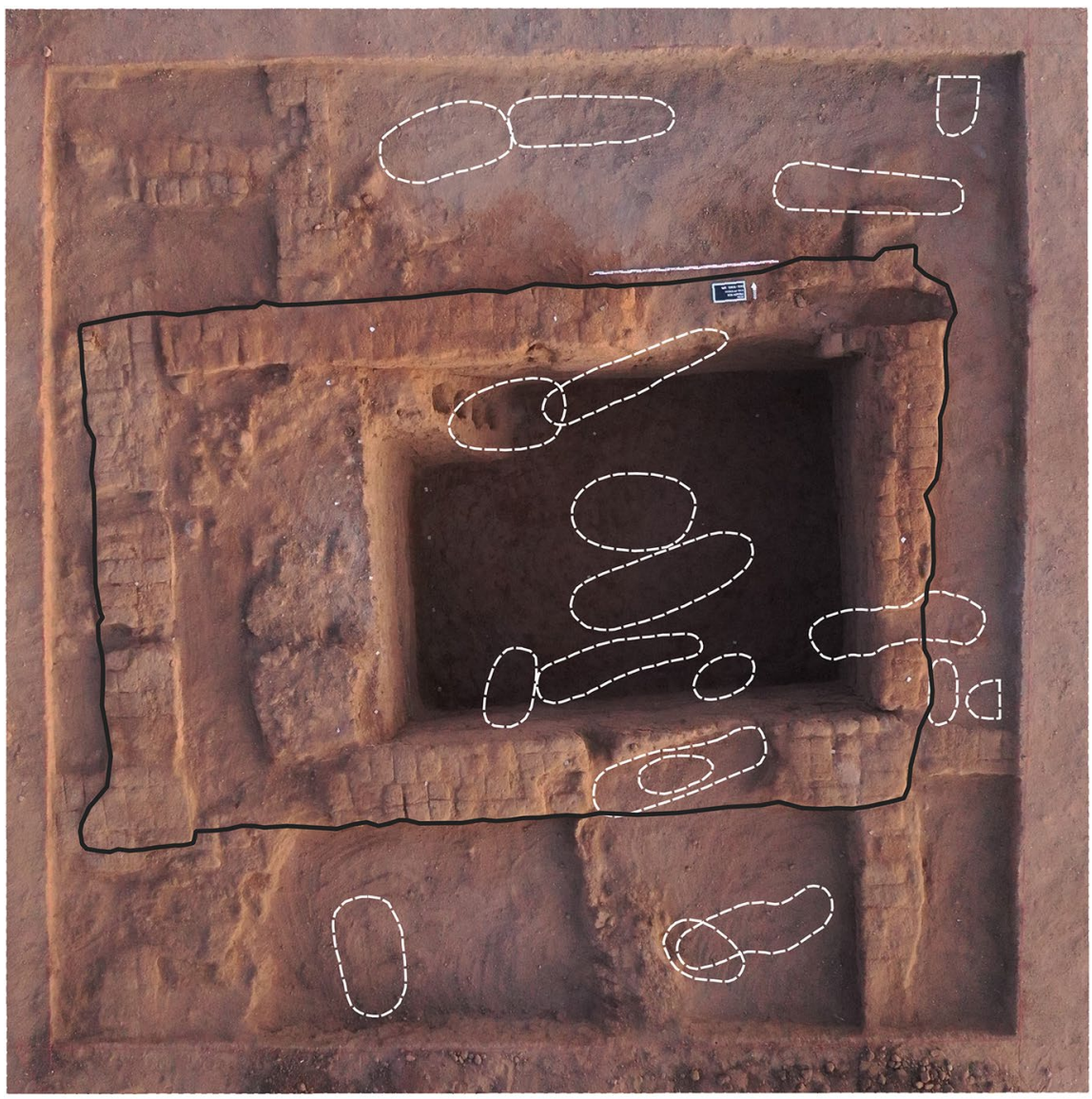

\section{Legend}

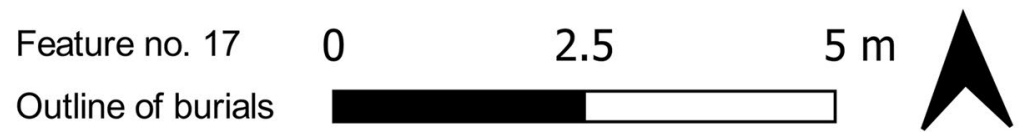

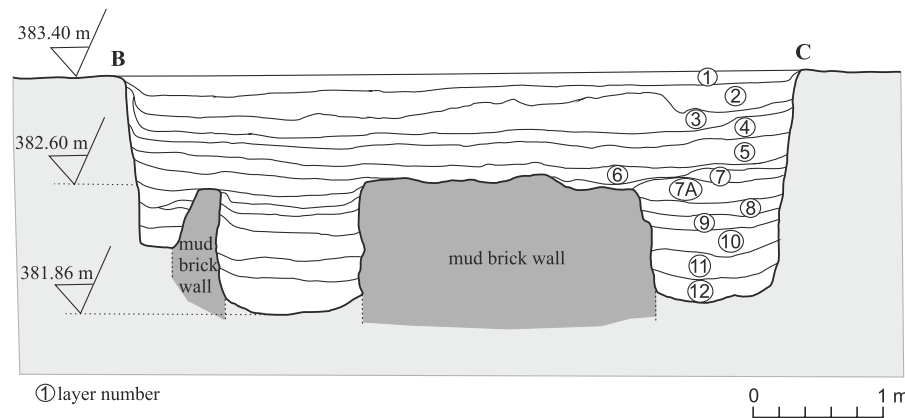

$\nabla_{\mathbf{B}}^{383.40 \mathrm{~m} /}$

Fig. 9 Cross-section of Mound CW (prepared by Mariusz Drzewiecki and Tomasz Michalik) 
Fig. 10 Trench $1 / \mathrm{CW}$ at the end of the excavation (photo Mariusz Drzewiecki)

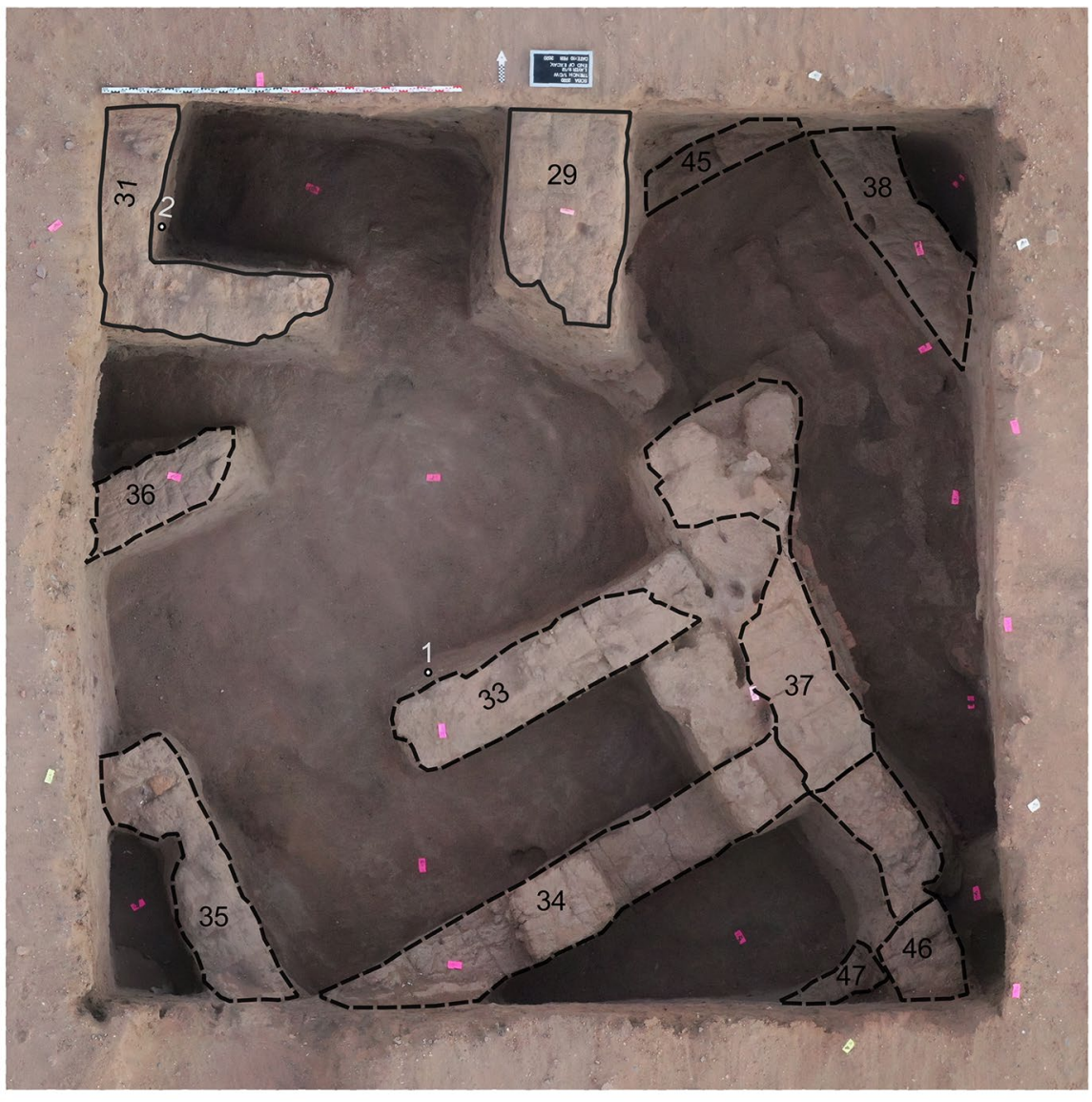

\section{Legend}

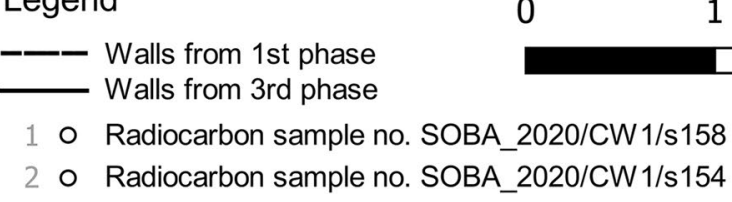

In trench $1 / \mathrm{CW}$, four occupation phases have been identified. The lowest is comprised of a mudbrick wall complex with small and elongated rooms (Fig. 10). Apparently, the organization of space was changing with time since some walls were found to be high and we could uncover their full preserved height, while others were set deeper and their foundations were not reached. Radiocarbon dates obtained from the foundation of wall no. 33 (see Fig. 10, spot no. 1) indicate that it was built after AD 527-615 at $68.6 \%$ probability (see Table 1 ). The second phase of occupation in $1 / \mathrm{CW}$ is connected with timber structures built after the mud-brick complex fell into ruin. Due to the limited size of the trench $(5 \times 5 \mathrm{~m})$, only several posthole cuttings into a compacted mud floor level were identified.

Phase three, with radiocarbon date AD 890-1013 (95\%), sees the return of mud-brick architecture parallel with timber constructions (the date comes from a sample taken from beneath wall no. 31, see Fig. 10 spot no. 2). Unlike the mud-brick architecture from the first phase, the younger structure was oriented $\mathrm{N}-\mathrm{S}$. The poor state of preservation does not allow us to specify the function of the building. The entire structure was heavily damaged by modern digging (phase four), which went deep and cut through phase two, ending at the upper levels of phase one. This feature, containing mixed materials, was probably the reason why magnetic readings were so obscure. 
When analyzing the amplitude of magnetic anomalies, it is possible to distinguish the building materials indirectly. Two major types that can be interpreted by reading the magnetic map are red-brick and mudbrick. Red-brick debris is marked on the interpretive map, most probably reflecting the destroyed buildings. Vast disturbances have been recorded not only at Mound $\mathrm{O}$ but also in areas $\mathrm{N}, \mathrm{HN}$, and around Church C. In one of the areas with dense mud-brick architecture (area F, see Figs. 3 and 7), two distinct types of anomalies were recorded. The readings are interpreted as walls and a linear feature. Both are likely the magnetic image of alleyways between buildings. The mutual spatial correlation of walls and passages indicates that these mud-brick buildings and alleyways were contemporary. The GPR mapping performed in this area seems to confirm these observations.

\section{Production Areas}

Hearths and kilns are notable characteristic features from the magnetic survey perspective. The high temperature within the kiln causes the material to acquire specific magnetic properties and, through creating high-intensity magnetization, can be easily identified on a magnetic map (Fassbinder, 2017, p. 504). Features interpreted as kilns and hearths are placed on the interpretative map in high correlation with other features related to the mud-brick constructions. Between them, often along the walls, there are legible anomalies interpreted as ash dumps. Trench $2 / \mathrm{OS}$ was set on one of the "kiln anomalies" on Mound OS. This area was a lime production zone, consisting of remains of mud-brick constructions and the residue of a lime kiln. Radiocarbon dating originating from the bottom of the lime deposit and another date (from the deposit above the lime layer) suggests that the lime deposit was formed in the first quarter of the eleventh century. After the abandonment, the southeastern part of Mound OS (like the central part) was used as a burial place. Although geophysical surveys have provided evidence that the development of Soba extended over an area much larger than that of the mounds, many areas appear to be devoid of or containing only minor remains of the settlement. This may be due to the looting of building materials from the site, but these areas may also have remained undeveloped during the medieval period occupation, or the remains could simply be eluding geophysical methods.

\section{Timber Architecture}

The survey did not identify the third type of building material used in Soba-timber. Such buildings were discovered during previous research (Welsby, 1998; Welsby \& Daniels, 1991) and in two of our trenches $(1 / \mathrm{SH}$ and $1 / \mathrm{CW})$. In the latter, they were documented as layers with multiple post holes and, in some cases, simultaneous with mud-brick structures. Timber architecture in trench $1 / \mathrm{SH}$ was erected after AD 892-1014 (95\%). A charcoal sample related to the final phase of the timber architecture provided a calibrated date of AD 986-1052 (63.8\%). Small circular (up to $0.8 \mathrm{~m}$ in diameter) and rectangular pieces (full size unknown) were recognized among the timber structures. Mud-brick architecture coexisted with the late phases of timber architecture. The topmost preserved remains were dated to the eleventh century. Such architectural features might have covered at least part of the area that is "empty" on the magnetic map, especially in the areas where it was possible to distinguish features interpreted as pits.

The magnetic properties of the archaeological structures are recorded in Soba, and the geological conditions in the Nile valley area make magnetometry a suitable tool for recognizing the spatial structure of Soba (Herbich, 2019, p. 197). However, attention should also be paid to the significant degree of destruction of numerous parts of the site and the presence of disturbances caused by modern infrastructure (e.g., power line poles and barbed wire iron fences). Geophysical research is also limited by the presence of modern houses, arable land, and the boundaries between them, as well as bushes and trees that cover part of the site. It should be understood that simple graves and timber structures are not represented on the map. Despite these limitations, the use of magnetometry has allowed for a completely new view of Soba's urban layout.

\section{Ceramics}

A large number of small finds were recorded. Pottery is the dominant category and the most commonly reported by the modern residents of Soba. Pottery examined so far comes only from trenches $2 / \mathrm{OS}$ 
and 1/O (Figs. 11 and 12). The main types of vessels recorded in these locations are presented below in the context of previous research carried out in the 1980s and 1990s (Welsby, 1998; Welsby \& Daniels, 1991). Three leading pottery groups have been identified: pots, jars, and bowls. Kitchenware/cooking pots are classified in groups A-D; storage jars are classified in groups $\mathrm{E}-\mathrm{H}$, and $\mathrm{J}$; specialized vessels, qawadis, are in group $\mathrm{J}$; large bowls (kitchenware), known as dokat, are grouped as category $\mathrm{K}$; and small bowls are classified in groups L-P.

The assemblages are similar and consist mainly of coarse wares. Handmade pottery is the largest group in the pottery assemblage (Fig. 13). They include the following:

1. Cooking pots (A) generally have wide straight or slightly out-flared rounded rim, short and broad neck, and globular body, mainly black (sometimes brown/red) burnished surface and sometimes slipped, and with grooved and incised decoration

2. Large handmade pots (B, C, D) (storage jars?) with rounded inturned rim, globular body, with grooved and sometimes incised decoration on the external surface

3. Storage jars (E, F), characterized by a wide outflaring rim, gradually develop into a narrow neck or jars with outflaring rim and short and broad neck

The RCW-HM (red fired, coarse ware, handmade) nondiagnostic handmade sherds probably belong to jars $(E, F, G)$. The vessels recorded in small quantities are handmade jars $(\mathrm{G})$, with a broad mouth and black slipped and burnished external surface, often referred to in the literature as "beer jars," and handmade bowls and pots with mat-impression on the body (J); and dokat (K) (cooking ware)-large handmade bowls characterized by thick walls and rounded rims, with burnished internal and plain external surfaces (Fig. 14).

Wheel-made pottery is represented by jars (Fig. 13H) with broad orifices and rounded straight or slightly out-flared rims. Qawadis (Fig. 13I) are vessels used for drawing water in conjunction with a waterwheel characterized by a knob-ended base, and the bottom part of the qadus is broader than the top. RCW-WM (red fired, coarse ware, wheel-made) presented here correspond to nondiagnostic wheelmade sherds, which probably belonged to qawadis (Fig. 13I) or storage jars (Fig. 13H) or even to drainpipes which were discovered in one layer.

Black and red burnished wares dominated the repertoire of small handmade and wheel-made bowls, such as handmade carinated bowls (Fig. 14L,M) with pointed inturned rims, black or red slip, and sometimes incised decoration. There are also black or red slipped bowls burnished on both surfaces (Fig. 14M$\mathrm{P}$ ), with plain rims and sometimes with grooved or painted decoration.

Imported, wheel-made pottery (Imp.) consists of very small sherds. In some cases, these were reused as disks or as plugs for closing off vessels (see Fig. 14, bottom 1-3). In trench 1/O (see Fig. 11), the pottery assemblage in the earliest layers (layers 8-5 dated to the ninth century) is not abundant and was found together with large quantities of animal bones. The most significant occupational phase was identified in layers 1-4 dated to the ninth through thirteenth century (Fig. 15). Here, the pottery assemblage, mainly cooking pots (D), dokat (K), handmade jars $(\mathrm{E}-\mathrm{F})$, black and red burnished bowls $(\mathrm{M}, \mathrm{N})$, and wheelmade jars $(\mathrm{H})$, was much more extensive and also contained animal bones and artifacts, such as stone tools, beads, and water-draining pipe fragments.

In trench 2/OS (Fig. 16), in the occupational layers 10 and 12 dated to the tenth and eleventh centuries (OS2/117 and OS2/119), mainly cooking pots (D), dokat (K), and qawadis (I), were recorded. Small black burnished bowls (M) were more common among the fine wares. In these layers, animal bones were also recorded. Some layers were connected with the occupation and production phase (see Figs. 13, 14, and 16). However, only two reused (nondiagnostic) sherds with traces of lime were recorded. The main occupation started with layers 8 and 7 dated to the eleventh century (OS2/093, OS2/090, OS2/092, OS2/091). Still, cooking pots (A, D) and dokat (K) were dominant. Among the fine wares, black and red burnished bowls are significant in number. In these layers, animal bones were also noted. The most plentiful pottery assemblages were discovered in layers $2-5$, postdating the eleventh century (OS2/084, OS2/089, OS2/088, OS2/083). Here, the high predominance of cooking pots (D) is notable. Also, the number of pots (A) and pots with mat-impressed patterns increased $(\mathrm{J})$. 
Fig. 11 Diagram showing the amount and the distribution of the pottery in all layers in Trench 1/O (prepared by Ewa CzyżewskaZalewska)

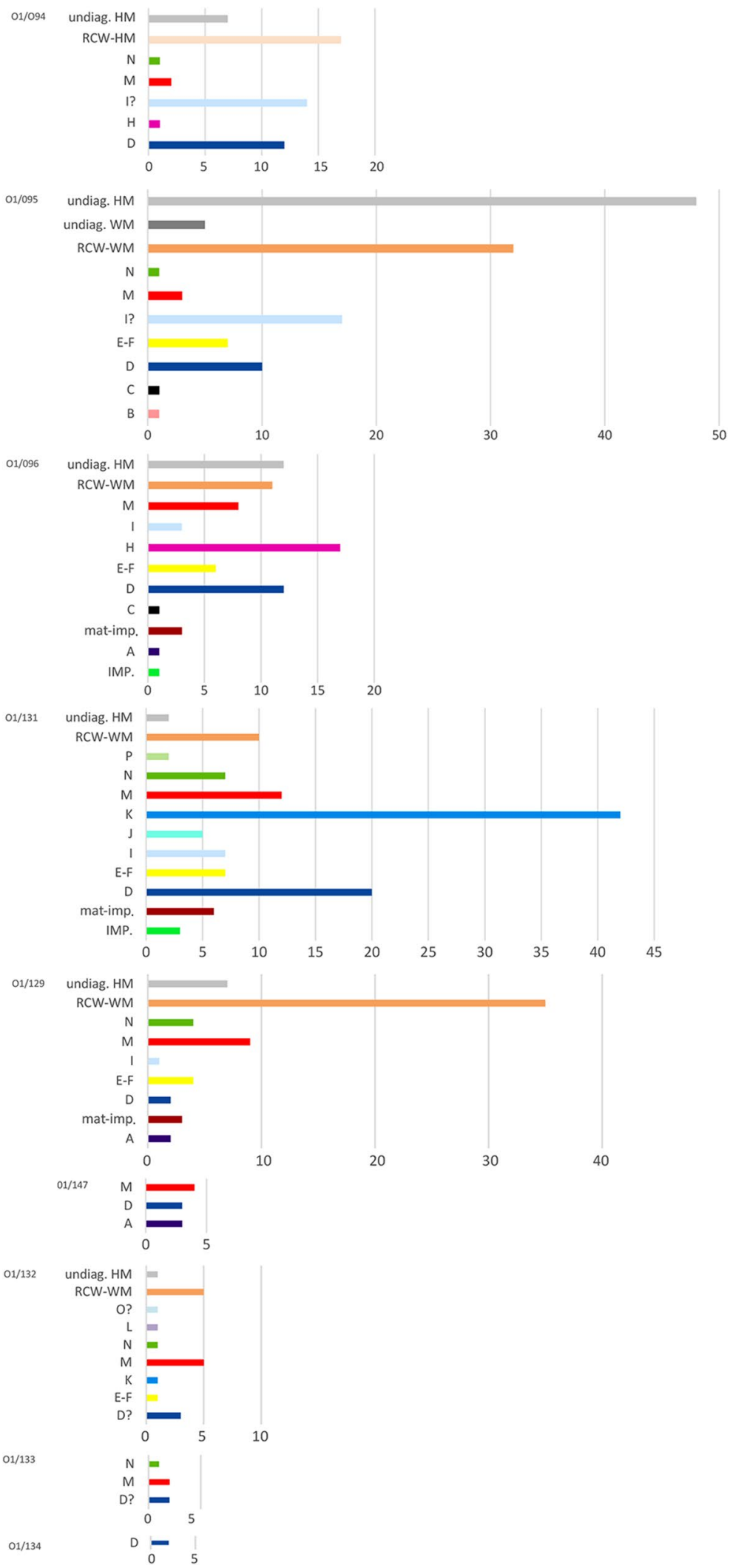


Fig. 12 Diagram showing the amount and the distribution of the pottery in all layers in Trench 2/OS (prepared by Ewa CzyżewskaZalewska)
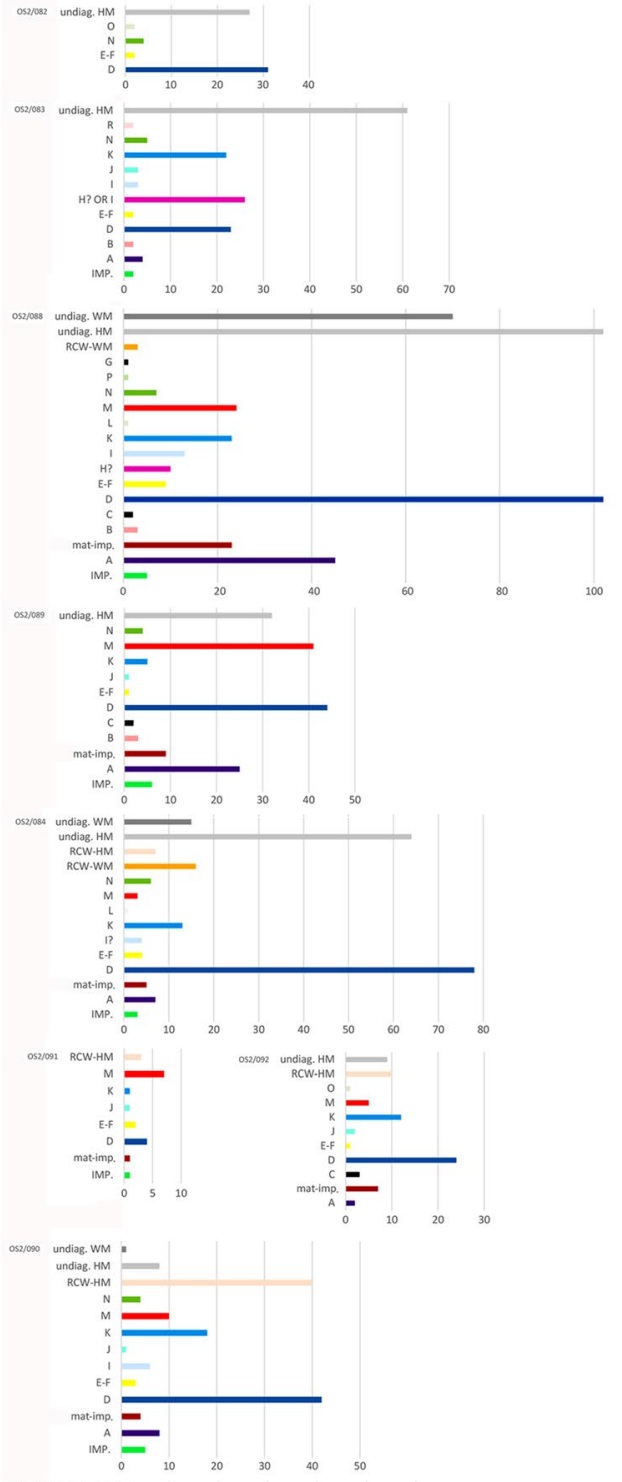

os:2003s undiog. WM $=$

Undiag. WM
undiag. HM
RCW-WM

${ }_{\mathrm{K}}^{\mathrm{N}}=$

$\underset{E-F}{H ?}=$

$\underset{A}{m_{0}^{E-f}}=$

IMP. $=10$

$\begin{aligned} 052 / 118 \quad R C W-W M & = \\ M & =- \\ D & =\end{aligned}$

IMP. : 5

oss/11, undiag. $\mathrm{HM}$
undias. WMM

RCW-HM

$\stackrel{P}{N}=$

in

$\underset{\mathrm{E}-\mathrm{F}}{\mathrm{H}}=$

$\begin{array}{lll}{ }_{0} & & \\ & & \end{array}$

${ }_{052 / 136} \mathrm{M}=$

m 

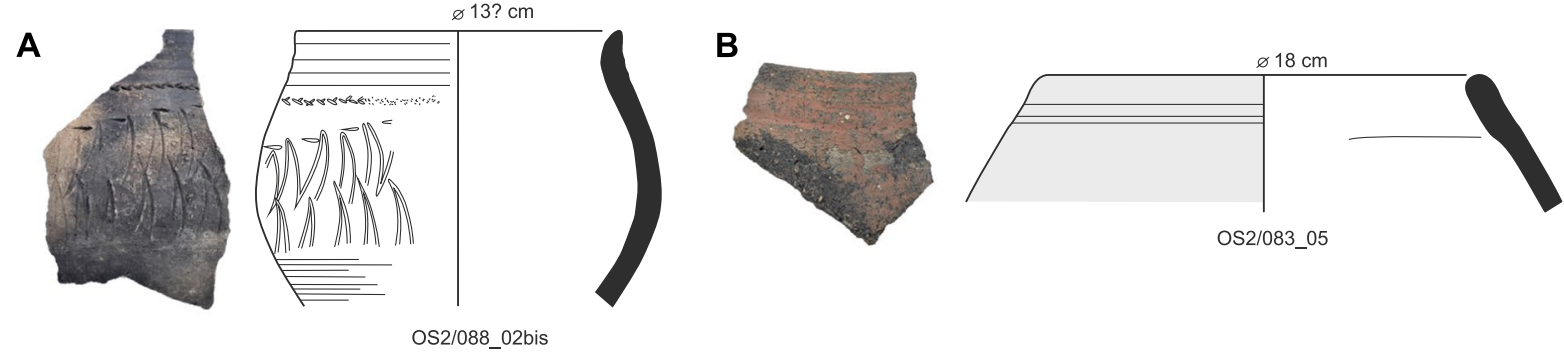

OS2/083_05

C
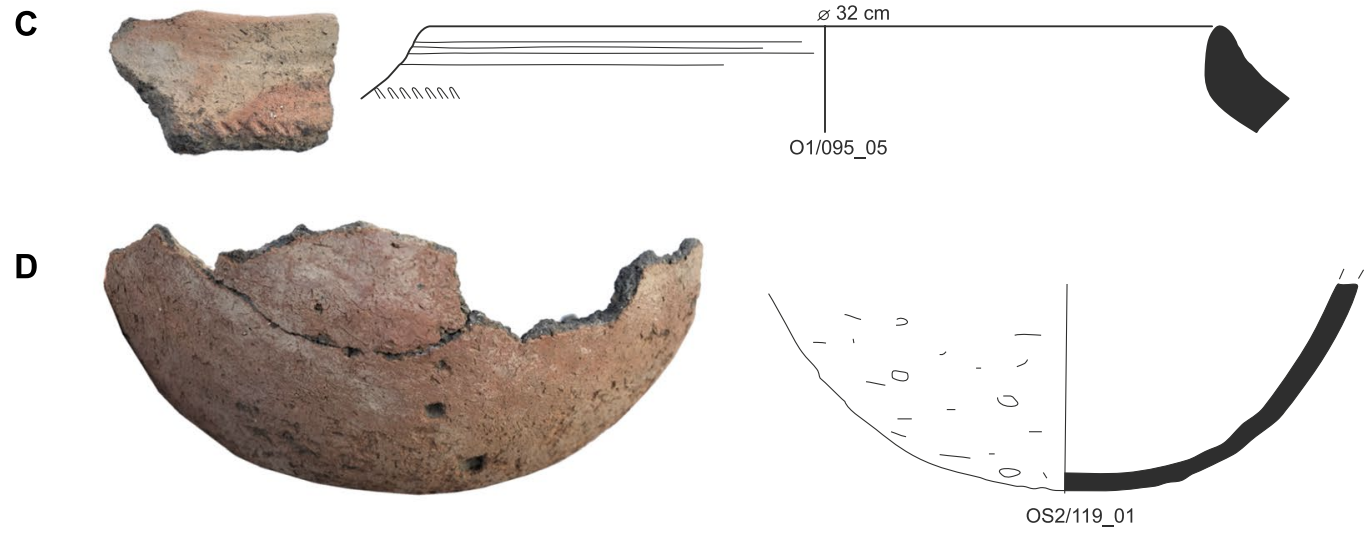

E
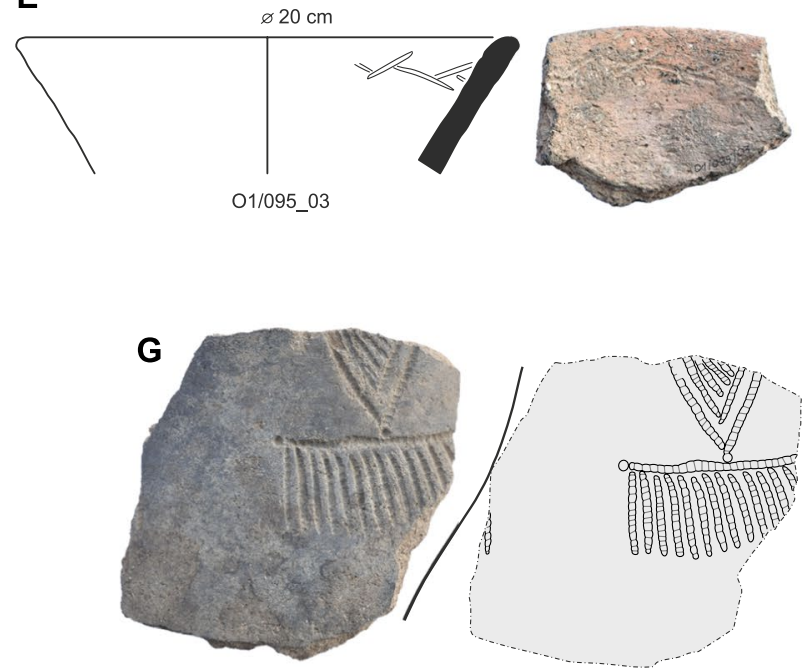

H
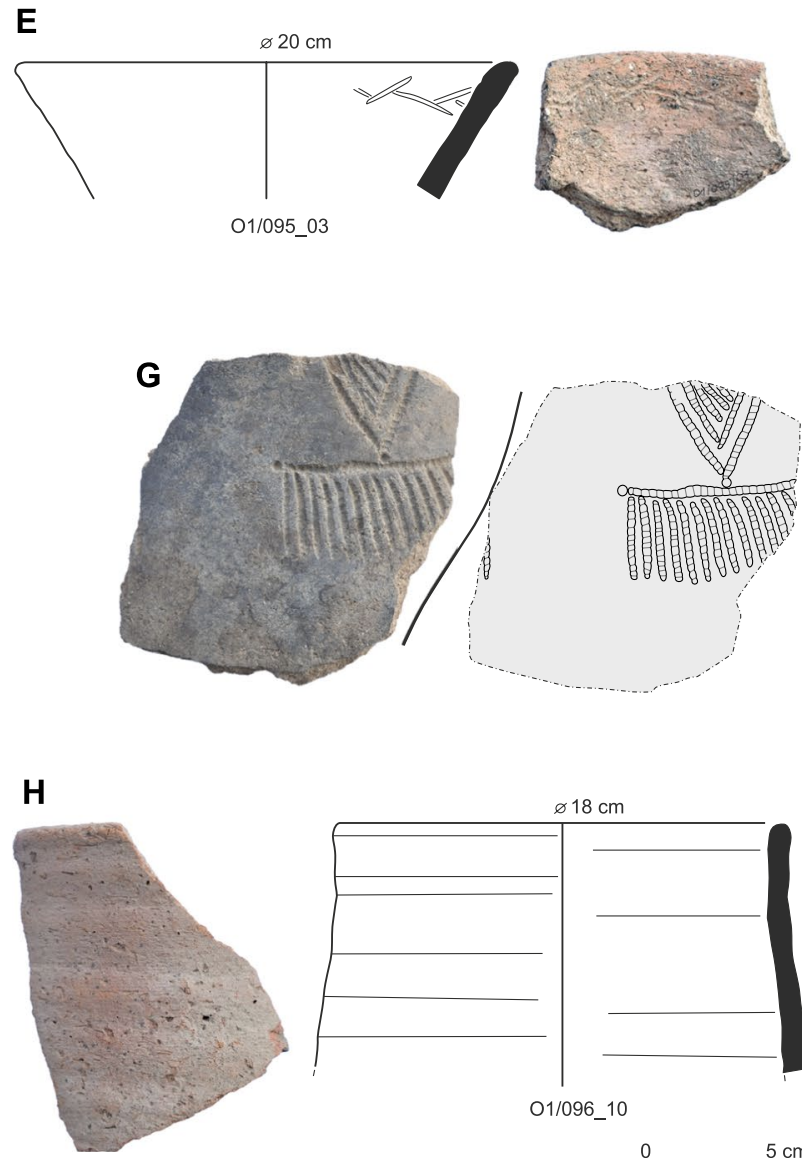

F
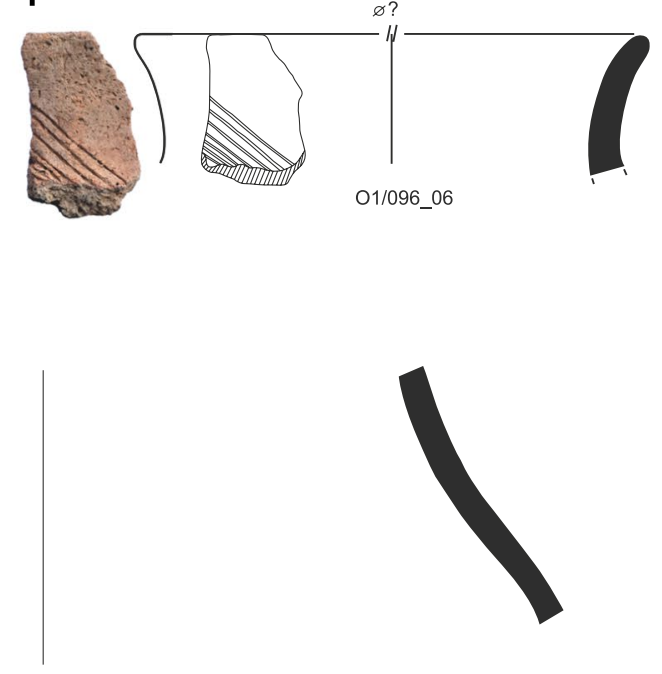

OS2/088_03
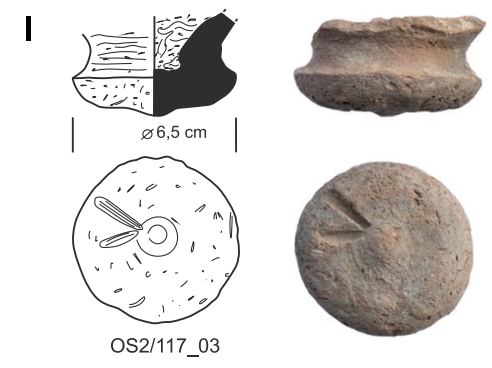

0 $5 \mathrm{~cm}$ 
4 Fig. 13 Hand-made pots, A-D and jars, E-G; wheel-made jars, $\mathrm{H}$ and qadus, I (prepared by Ania Weźranowska, Marta Momot and Ewa Czyżewska-Zalewska)

The quantity of black burnished bowls (M) also increased in comparison to the earliest occupation layers. These contexts yielded animal bones as well as stone tools and other artifacts.
The coarse and fine wares described above fit well into the pottery collection recorded during previous research (Welsby, 1998; Welsby \& Daniels, 1991). Handmade pots (A) correspond probably to Class L, types 37, 39, 43, 69, 77 (Welsby \& Daniels, 1991, p. 179, 185, Figs. 98, 100). Large handmade pots (B-D) correspond probably to Class I, types 1-11 vessels (Welsby \& Daniels, 1991, p.

\section{J}

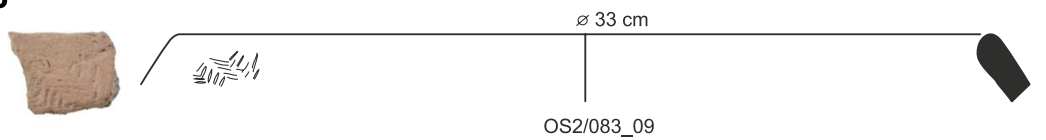

\section{$\mathbf{K}$}
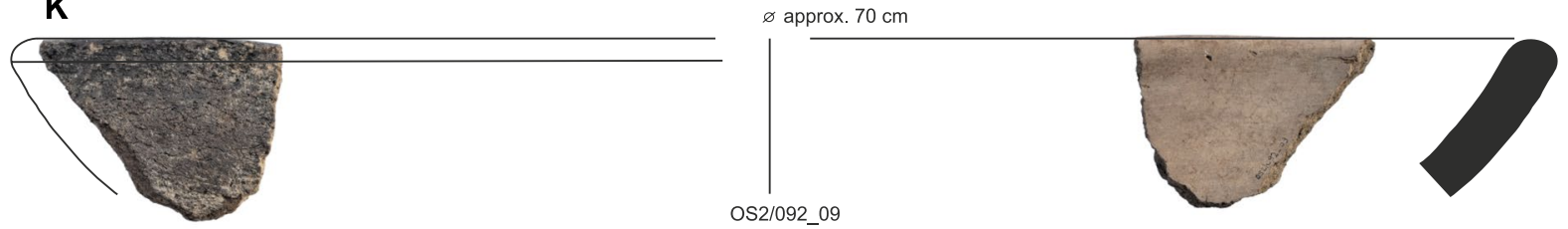

$\mathbf{L}$

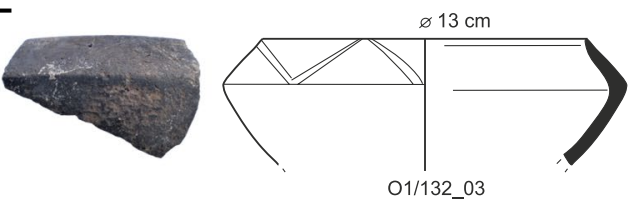

M

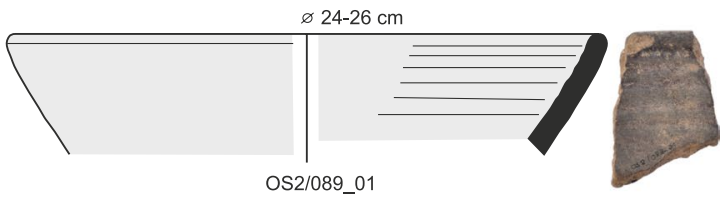

N

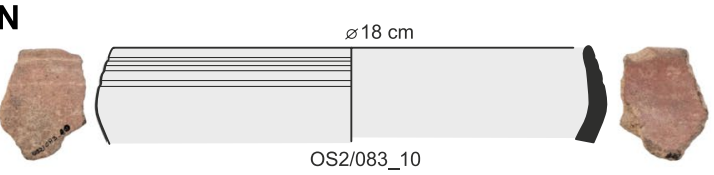

0

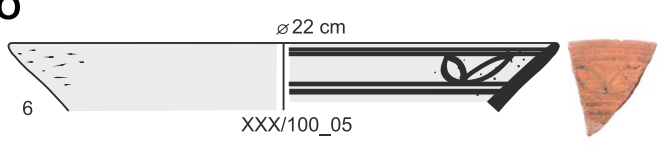

P

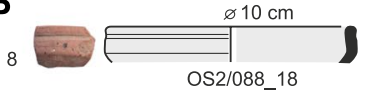

$0,, \quad 5 \mathrm{~cm}$
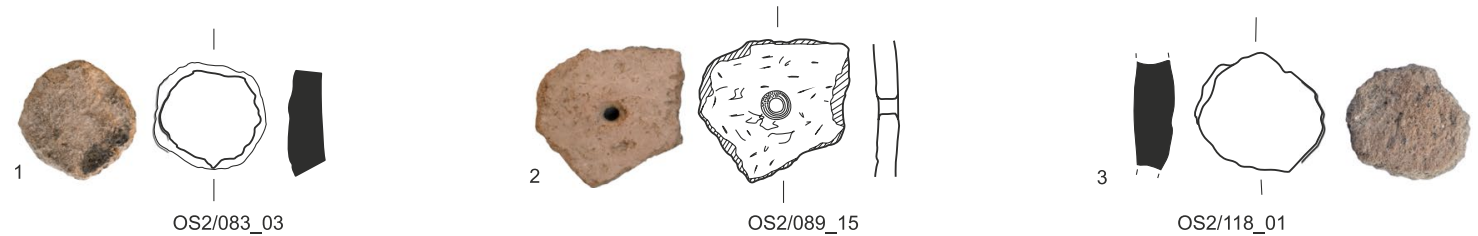

OS2/118_01

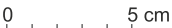

Fig. 14 Hand-made bowl with mat-impressed pattern-J, hand-made dokat-K, and small carinated bowls-L), and small wheel-made slipped bowls-M-P (prepared by Ania Weźranowska, Marta Momot, and Ewa Czyżewska-Zalewska) 


\section{Trench 1/0}
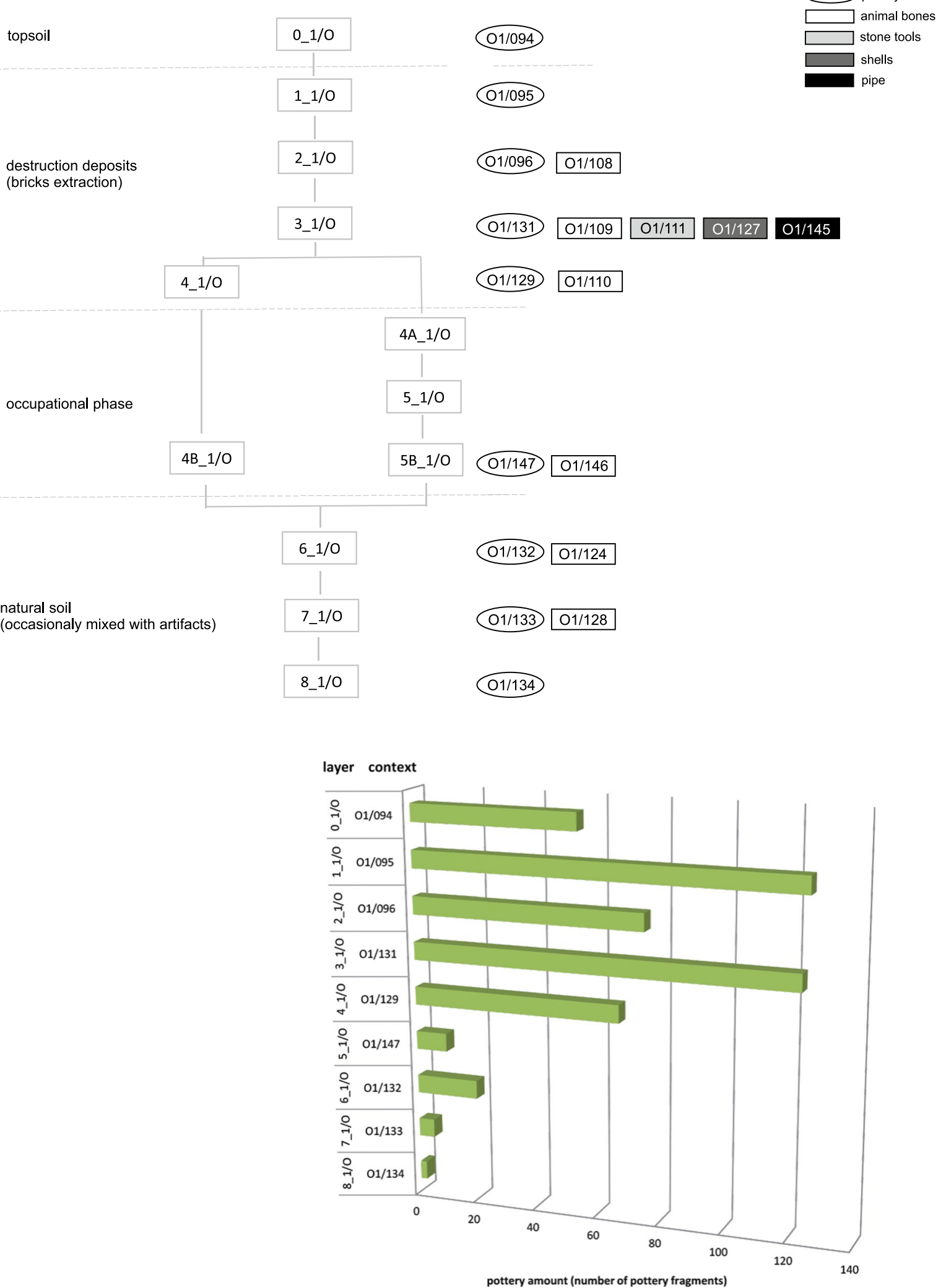
4Fig. 15 Trench 1/O: the distribution of different groups of artifacts (top) and distribution of pottery in all layers of the trench (bottom) (prepared by Tomasz Michalik and Ewa Czyżewska-Zalewska)

179, Fig. 91). Handmade jars (E-F) are the same as Class A vessels (Welsby \& Daniels, 1991, p. 165-66, figs. 82-83), while Dokat (K) corresponds to Class K (Welsby \& Daniels, 1991, p. 175-78, Figs. 89-90). The small wheel-made and handmade bowls, black or red slipped and burnished on both surfaces (M, N, O), belong to Class $\mathrm{N}$ and types 76, 121, 172-174, 201 of pottery (Welsby \& Daniels, 1991, p. 193, Figs. 106, 110, 112, 113). Qawadis (I) are comparable to Class G (Welsby \& Daniels, 1991, p 175-78, figs. 89-90).

The two trenches $1 / \mathrm{O}$ and $2 / \mathrm{OS}$ did not yield the most distinctive fine ware, Soba ware, characteristic of the early Medieval occupation in the capital (sixth through the eighth or ninth century AD). However, since the layers of the first centuries of the period do not always contain such material, radiocarbon dating resolved the issue (see Table 1), indicating that the features discovered in 1/O and 2/OS should be associated with the later phases of Soba (ninth century and later). The homogeneity of the ceramic assemblage from the site has been noted before (Welsby, 1991, p. $12 ; 1998$, p. 87-177), and the situation is the same for the most recently excavated materials. The vessels are similar in terms of execution, style, and form, showing that the inhabitants of medieval Soba were using quite uniform sets of ceramics. This observation can be used to study the assemblage collected as random finds by the residents.

Some of the roughest coarse wares may have been homemade. However, the fine wares (black and red polished wares) required expertise and controlled conditions to be manufactured. Do they come from a single workshop? The only pottery kiln discovered so far was in the western part of Mound B and might be associated with the production of qawadis and dokat, indicated by large quantities of these types of vessels recorded in the vicinity (Welsby, 1991, p. 12; Welsby \& Daniels, 1991, p. 103-106).

\section{Conclusion}

The ethnological survey showed that the residents have daily contact with antiquities. Most respondents had something to say when asked about stories or legends connected with the site and its artifacts. In the life of Soba residents, the tales often resurfaced when news about accidental finds started to circulate. The arrival of archaeologists was also stimulating in this respect. Our respondents understand the remains of Soba as something from the past which was not built by their ancestors but still bears similarities with traditional material culture. Soba is chiefly thought of as the remains of a capital erected by Christians. Residents were bewildered upon hearing that, according to Arab medieval travelers, the city hosted various peoples, including Muslims. Their beliefs had been shaped by oral histories and elementary school teaching, which presented Soba in the context of its fall, the arrival of Islam, and the rise of the Funj Sultanate. Soba is also understood as an "empty" land that should be used for cultivation or to build new houses. There is a need for land in the Greater Khartoum area. With its tarmac road and a new bridge connection with the capital, Soba is a convenient place to settle.

All these issues are constantly overlapping, mixing, and influencing the views of the residents. This results in the various reactions of the community to archaeological heritage and, by extension, to archaeologists. It can vary from hostile or neutral to open and helpful relationships (see also Näser, 2019). All the respondents were convinced that the archaeologists would leave and take all discovered 'treasures' with them, and that the local community, as always, will not benefit from it in the long term. This mistrust of archaeologists is challenging, but things can be improved through outreach and community engagement activities. Although such activities have been undertaken in Sudanese Nubia, they have never taken place in urban communities (Bradshaw, 2017; Fushiya, 2020; 


\section{Trench 2/OS}
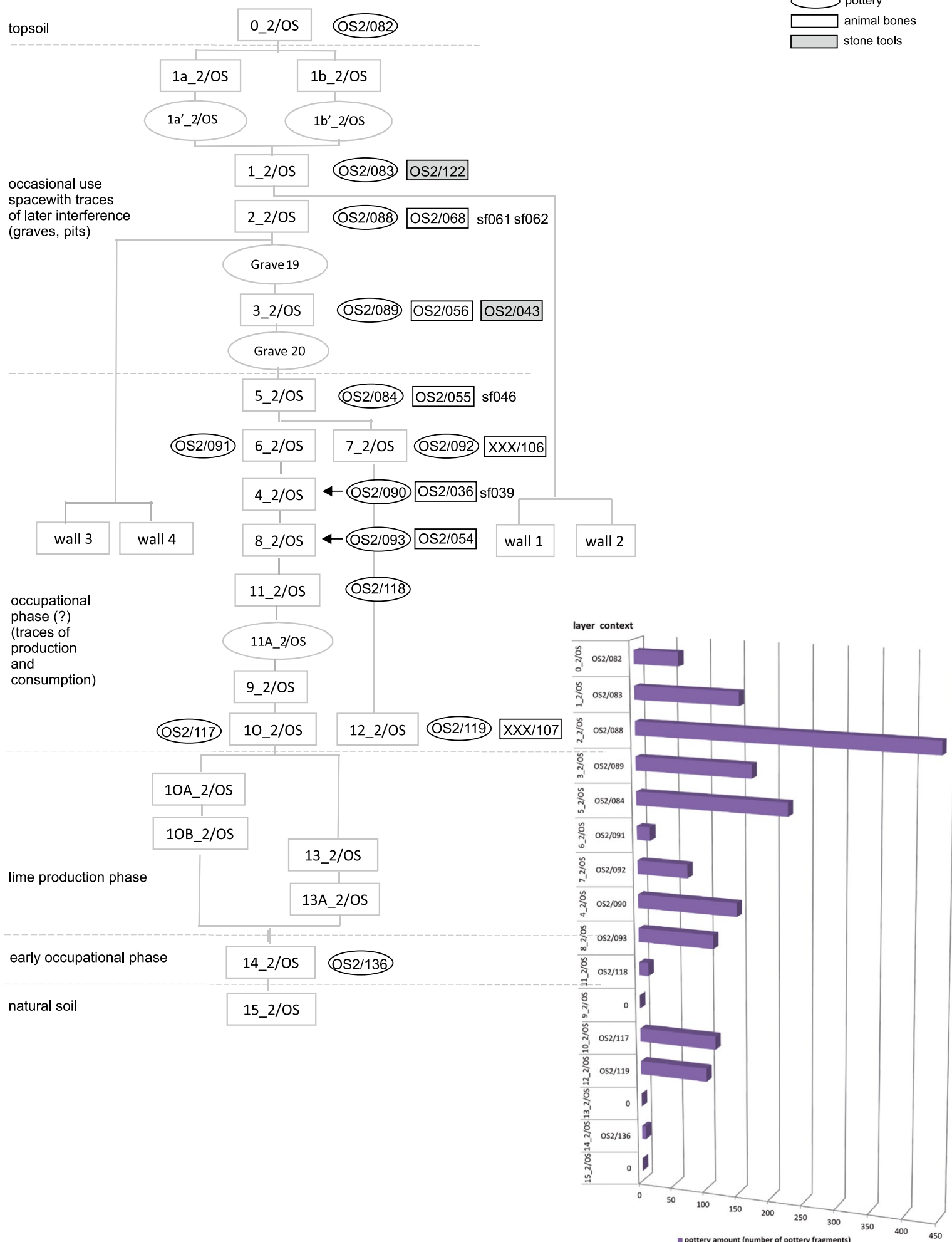
4Fig. 16 Trench 2/OS, the distribution of different groups of artifacts (top) and distribution of pottery in all layers of the trench (bottom) (prepared by Tomasz Michalik and Ewa Czyżewska-Zalewska)

Humphris \& Bradshaw, 2017; Humphris et al., 2021; Tully \& Näser, 2016). A two-way knowledge transfer should be established in Soba between the local community and the archaeological research teams. Residents need to be presented with the aims and results of the ongoing studies, and a path should be opened for the residents to express their opinions and contribute to the research by providing local oral histories. Working together means that dialog between various interest groups linked to the archaeological zone in Soba is essential. In this context, the Sudanese inspectors could play a significant role in establishing contacts with all groups involved. It will create an environment for future consultations about the long-term strategies in research and development.

The first steps were taken in the 2019-2020 season. The local primary schools were visited. There, the ethnologist introduced the research team, and we discussed our work and the local heritage. In January 2020, the construction of an archaeological store began at Soba (next to the police station). Ultimately, all small finds from our research in Soba will be stored there. This solution was chosen for two reasons. On the one hand, all materials will be available in one place for researchers. On the other hand, this is an attempt to change the local community's attitude to show that our aim is not to export the artifacts.

With the community becoming more open and familiar with archaeologists and their work, systematic studies are possible, and new research questions can be developed. The observations and detailed studies of architectural remains and artifacts obtained from well-defined contexts within the 53-ha undisturbed part of Soba would provide the guideline for research in the developed parts of the site. Thus, the research conducted in both areas would be linked. The most intriguing observation from the recent fieldwork is that the architectural remains of medieval Soba are not only preserved under the mounds but can also be found under the flat surface of the site. The mounds themselves hide substantial architectural remains, which were extensively used in the last phases of the medieval city.

During the fieldwork in 2019-2020, the early Medieval remains were visible in trench $1 / \mathrm{CW}$, approximately one meter below the surface. The geophysical survey in this part of the site recorded various architectural features. They were not so clearly visible compared to the easily identifiable later remains in areas $\mathrm{F}$, OS, and $\mathrm{H}$. The archaeological features deep under the ground-level in trench $1 / \mathrm{CW}$ indicate that the surrounding agricultural areas may still hide remains of medieval Soba. Since excavations in such areas would meet with hostility from the farmers, the remote sensing method should be applied. Magnetic as well as GPR methods should be able to detect architectural remains under the fields. Geophysical prospection can also be undertaken between houses in all parts of the modern settlement. The most promising are empty squares. However, modern garbage and metal trash lying around will constitute a major obstacle. Thus, for the research between the houses, GPR seems to be more suitable than the magnetic survey.

The involvement of cultural anthropologists is essential to link with and understand the modern community of Soba and to obtain information about the finds. Among chance finds reported in 2019-2020, particularly interesting are reports of human remains. Following and mapping such information can lead to the location of major medieval cemeteries, which probably existed on the outskirts of the capital and are currently somewhere under the modern buildings. The research potential of Soba is great, and the sections of the site that are built up or converted to farmlands are not entirely lost. A well-tailored research agenda, in which the local community plays a key role, is needed to study such developed areas.

Open Access This article is licensed under a Creative Commons Attribution 4.0 International License, which permits use, sharing, adaptation, distribution and reproduction in any medium or format, as long as you give appropriate credit to the original author(s) and the source, provide a link to the Creative Commons licence, and indicate if changes were made. The images or other third party material in this article are included in the article's Creative Commons licence, unless indicated otherwise in a credit line to the material. If material is not included in the article's Creative Commons licence and your intended use is not permitted by statutory regulation or exceeds the permitted use, you will need to obtain permission directly 
from the copyright holder. To view a copy of this licence, visit http://creativecommons.org/licenses/by/4.0/.

\section{References}

Abdel Rahman, A. M. (2000). Rescue excavations at Soba East. Sudan and Nubia, 4, 27-31.

Bradshaw, R. (2017). Beyond identity: The socio-economic impacts of archaeology on a non-descendant community in Sudan. Ph.D. thesis, University of London. http://eprin ts.soas.ac.uk/26653.

Budge, E. A. W. (1907). The Egyptian Sudan, its history and monuments (Vol. 1). Lippinott.

Chataway, J. D. P. (1930). Notes on the history of the Fung. Sudan Notes and Records, 13, 247-258.

Ciesielska, J. A., Obłuski, A., \& Stark R. J. (2018). The cemeteries of Ghazali, season 2015/2016. In A. Lohwasser, T. Karberg, \& J. Auenmüller (Eds.), Bayuda Studies. Proceedings of the First International Conference on the Archaeology of the Bayuda Desert in Sudan (Meroitica) (pp. 257-227). Westfälische Wilhelms-Universität Münster Institut für Ägyptologie und Koptologie.

Drzewiecki, M., Ryndziewicz, R., Ciesielska, J., Michalik, T., Kurcz, M., Czyżewska-Zalewska, E., \& Adam, R. A. (2020). New fieldwork in Soba East (season 20192020). Sudan and Nubia, 24, 233-246.

Edwards, D. N. (2004). The Nubian past: An archaeology of the Sudan. Routledge.

Fassbinder, J. W. E. (2017). Magnetometry for archaeology. In A. S. Gilbert (Ed.), Encyclopedia of Geoarchaeology (pp. 499-514). Springer. https://doi.org/10.1007/ 978-1-4020-4409-0

Glazier, D. (2003). We make the diamond shine: Archaeological communities in Quseir, Egypt. Ph.D. thesis, University of Southampton.

Fushiya, T. (2020). Valuing archaeology? The past, present, and future for local people and archaeologists in Sudanese Nubia. Ph.D. thesis, Leiden University.

Fushiya, T., \& Radziwiłko, K. (2019). Old Dongola community engagement project: Preliminary report from the first season. Sudan and Nubia, 23, 172-181.

Herbich, T. (2019). Efficiency of the magnetic method in surveying desert sites in Egypt and Sudan: Case studies. In R. Persico, S. Piro, \& N. Linford (Eds.), Innovation in near-surface geophysics (pp. 195-251). Elsevier. https:// doi.org/10.1016/b978-0-12-812429-1.00007-6

Humphris, J., \& Bradshaw, R. (2017). Understanding "the community" before community archaeology. The Journal of Community Archaeology and Heritage, 4(3), 203-217.

Humphris, J., Emberling, G., \& Bradshaw, R. (2021). Archaeological practice in the 21 st century. Reflecting on archaeologist-community relationships in Sudan's Nile Valley. In G. Emberling \& B. B. Williams (Eds.), The Oxford handbook of Ancient Nubia. Oxford University Press. https:// doi.org/10.1093/oxfordhb/9780190496272.013.57

Jackson, H. C. (1926). A trek in Abu Hamed district. Sudan Notes and Records, 9(2), 1-35.
Kurcz, M. (2007). Za trzecia katarakta. Życie codzienne wsi pótnocnosudańskiej. Polskie Towarzystwo Ludoznawcze.

Lenoble, P. (1987). Quatre tumulus du mille au Djebel Makbor. AMS NE-36-O/3-X-1. Archéologie Du Nil Moyen, 2, 207-247.

Lepsius, K. R. (1853). Letters from Egypt, Ethiopia, and the Peninsula of Sinai. Henry G. Bohn.

Lepsius, K. R. (1913). Denkmäler aus Aegypten und Aethiopien. Fünfter Band: Nubien, Hammamat, Sinai, Syrien und Europäische museen. J.C. Hinrichs'sche Buchhandlung.

MacMichael, H. A. (1922). A history of the Arabs in the Sudan and some account of the people who preceded them and of the tribes inhabiting Dárfür. Cambridge University Press.

Näser, C. (2019). Exploring attitudes towards the archaeological past: Two case studies from majority Muslim communities in the Nile valley. Journal of Social Archaeology, 19(3), 379-402. https://doi.org/10.1177/1469605319 867194

Nora, P. (2009). Między pamięcią i historią. Les Lieux de Memoire (trans. P. Mościcki). Working Title Archive, 2, 4-12.

Osman, A. M. S. (1992). The folklore of archaeological sites: A case study from Nawri in Third Cataract region. In J. Sterner \& N. David (Eds.), An African commitment: Papers in Honour of Peter Lewis Shinnie (pp. 31-35). University of Calgary Press.

Rebillard, E. (2009). The care of the dead in Late Antiquity. Cornell University Press.

Rebillard, E. (2013). Transformations of religious practices in Late Antiquity. Ashgate.

Reisner, G. A. (1910). The archaeological survey of Nubia: The report for 1907-08 archaeological report (Vol. 1-2). National Printing Department.

Rilly, C., \& Francigny, V. (2011). The Late Meroitic cemetery at Sedeinga. Campaign 2010. Sudan \& Nubia, 15, 72-79.

Seignobos, R. (2016). L'Égypte et la Nubie à l'époque médiévale. Élaboration et transmission des savoirs historiographiques (641 - ca. 1500). Ph.D. thesis, Université Paris 1 Panthéon-Sorbonne.

Shinnie, P. L. (1955). Excavations at Soba. Sudan Antiquities Service Occasional Papers 3. Sudan Antiquities Services.

Schmidt, A. R., Linford, P., Linford N., David, A., Gaffney C. F., Sarris A., \& Fassbinder, J. W. E. (2015). EAC Guidelines for the use of geophysics in archaeology: questions to ask and points to consider. EAC Guidelines 2. Namur, Belgium.

Somers Clarke, G. (1912). Christian antiquities in the Nile Valley. a contribution towards the study of the ancient churches. Clarendon Press.

Tully, G. (2014). Community archaeology on Mograt Island: Sharing spaces, understanding sites. Mitteilungen Der Sudanarchäologischen Ge-Sellschaft Zu Berlin, 25, 1-6.

Tully, G. (2015). Community archaeology in Sudan: Discovering Mograt Island together. Mitteilungen Der Sudanarchäologischen Gesellschaft Zu Berlin, 26, 201-204.

Tully, G., \& Näser, C. (2016). Discovering Morgat Island together. Golden House Publications.

Vantini, G. (1975). Oriental sources concerning Nubia. Polish Academy of Sciences and Heidelberger Akademie der Wissenschaften. 
Volp, U. (2002). Tod und ritual in den christlichen Gemeinden des Antike. Supplements to Vigiliae Christianae 65. Brill.

Welsby, D. A. (1991). Pottery production and supply at Soba East. In W. Godlewski (Ed.), Coptic and Nubian Pottery, Part II, International Workshop, Nieborow, August 29-31, 1988 (pp. 10-17). National Museum in Warsaw.

Welsby, D. A. (1998). Soba II, renewed excavations at the metropolis of the Kingdom of Alwa. British Institute in Eastern Africa Monograph Series 15. The British Museum Press.

Welsby, D. A. (2002). The medieval kingdoms of Nubia: Pagans. The British Museum Press.

Welsby, D. A. (2005). The Merowe Dam Archaeological Salvage Project Survey in the vicinity of ed-Doma (AKSE), 2004-2005. Sudan \& Nubia, 9, 2-8.
Welsby, D. A., \& Daniels, C. M. (1991). Soba: Archaeological research at a medieval capital on the Blue Nile. Memoirs of the British Institute in Eastern Africa 12. The British Museum Press.

Publisher's Note Springer Nature remains neutral with regard to jurisdictional claims in published maps and institutional affiliations. 